\title{
PUBLIC PERCEPTION OF ENVIRONMENTAL, SOCIAL AND ECONOMIC IMPACTS OF URBAN SPRAWL IN VILNIUS
}

\author{
Paulo Pereira* \\ Environmental Management Center, \\ Mykolas Romeris University, \\ Ateities str. 20, LT-08303 Vilnius, Lithuania \\ E-mail:paulo@mruni.eu \\ Algirdas Monkevičius \\ Environmental Management Center, \\ Mykolas Romeris University, \\ Ateities str. 20, LT-08303 Vilnius, Lithuania \\ E-mail: securid1@gmail.com

\section{Hanna Siarova} \\ Public Policy and Management Institute, \\ Gedimino av. 50, LT-01110 Vilnius, Lithuania \\ E-mail: hanna.siarova@gmail.com
} Received on 4 February, 2014; accepted on 2 June, 2014

doi:10.13165/SMS-14-6-2-03

Abstract.Urban sprawl is recognized to have strong negative impacts on environmental, social and economic aspects. The expansion of the urban areas has important effects on energy and water consumption, air and water pollution, human health problems, soil and land consumption and degradation, as economic and

${ }^{\star}$ Correspondent author 
social segregation and exclusion. The aim of this paper is to study the Vilnius public perception about urban sprawl in the environmental, social and economic dimensions, according to the age and professional occupation of the respondents. The results showed that the participants were concerned about urban sprawl effects. However, there were differences among ages and professional occupations. Younger people that worked in NGO and municipality gave more importance to the problem, and older government and municipally workers claimed for a better regulation. The perception of urban sprawl impacts on the environment were specially observed in consumption, pollution and human health, and less in soil, land degradation and resource depletion. Younger respondents valued more the impacts on air pollution, whereas government workers valued more the impacts in traffic aspects. The social and economic questions were considered all very important. Younger respondents were more concerned with the long distance travels and household expenditure than the older respondents. This last group claimed for more regulations and rated high the effects of urban sprawl in the rural environment, while young respondents - in urban areas.

Keywords: urban sprawl, environmental, social, economic, public perception.

\section{Introduction}

Urban sprawl describes the physical expansion of low density urban areas into forest and agricultural environments ${ }^{1}$. This phenomenon is one of the most important causes of land use change across the world ${ }^{2}$. Presently, more than a quarter of the European Union's territory is directly affected by urban expansion, and it is estimated that by 2020 approximately $80 \%$ of the European population will live in urban environments. This land use change has strong implications on resources demand and conflicts that are shifting the landscapes dramatically around the cities. In Europe, it is regarded as one of the major problems of the urban areas development ${ }^{3}$.

1 EEA. 2006. Urban Sprawl in Europe. The Ignored Challenge. European Environmental Agency Report. 10: 56.

2 Hasse, J.E.; Lathrop, R.G. 1995. Land Resource Impact Indicators of Urban Sprawl. Applied Geography. 23(2-3): 159-175.; Bart, I.L. 2010. Urban Sprawl and Climate Change: A Statistical Exploration of Cause and Effect, with Policy Options for the EU. Land Use Policy. 27(2): 283-292.; Zhao, P. 2010. Sustainable Urban Expansion and Transportation in a Growing Megacity: Consequences of Urban Sprawl for Mobility on the Urban Fringe of Beijing. Habitat International. 34(2): 236-243.; Travisi, C.M.; Camagni, R.; Nijkamp, P. 2010. Impacts of Urban Sprawl and Commuting: A Modelling Study for Italy. Journal of Transport Geography. 18(3): 382-392.

3 EEA. 2006. Urban Sprawl in Europe. The Ignored Challenge. European Environmental Agency Report. 10: 56.; European Commission. 2011. Cities of Tomorrow. Challenges, Visions, Ways forward. Directorate General for Regional Policy, p. 100. 
The urban sprawl causes are attributed to the expensive lifestyles, cultural views, the increase of human mobility, the search for less expensive houses than in the city center, the low cost and development of the transport network and population increase, competition among municipalities, poor air quality in the city, noise, small apartments, unsafe environments, lack of green areas, poor quality of schools and social problems ${ }^{4}$. The implications of this are the increase of agricultural land loss, biodiversity reduction, resource depletion, ecological stress and disturbance, runoff and flood potential increase, loss of cultural values, urban heat island expansion, increase of energy consumption, traffic circulation, increase in municipal expenses, release of greenhouse gases, climate change, air, soil, water and noise pollution, human health problems, spatial segregation and social exclusion. These aspects have a direct and indirect impact on urban areas life quality ${ }^{5}$.

Public perception and opinion are key aspects to influence policy making ${ }^{6}$. In European Union countries, there is an increasing concern about the impacts of environmental damage in social and economic aspects. To Europeans, environment protection is highly important. According to European Commission ${ }^{7}$, when people talk about the environment, the greatest part of persons associates it with pollution in towns and cities. Urban sprawl is one of the main causes of pollution in urban areas. Despite the importance of the problem, little research has been carried out in Europe about public perception impacts of urban sprawl in environmental, social and economic aspects.

Historically, cities in Eastern Europe have been compacted. During the communist time, compact cities and high densities reflected the strong centralized regime and dependence on public transports. With the political change, these cities were exposed to the same risk of urban sprawl as the western cities. In the recent years, the expansion outwards have been remarkable. In the last 20 years, the build-up areas have increased by $20 \%$, and the population has increased only by $6 \%$ ${ }^{8}$. After the collapse of the Soviet Union, the suburbanization rate in eastern cities was higher than in the western urban areas. This boom was a product of internal

EEA. 2006. Urban Sprawl in Europe. The Ignored Challenge. European Environmental Agency Report. 10: 56.; Jaeger, J.A.G.; Bertiller, R.; Schwick, C.; Kienast, F. 2010. Suitability Criteria for Measures of Urban Sprawl. Ecological Indicators. 10(2): 397-406.

5 EEA. 2006. Urban Sprawl in Europe. The Ignored Challenge. European Environmental Agency Report. 10: 56.; European Commission. 2011. Cities of Tomorrow. Challenges, Visions, Ways forward. Directorate General for Regional Policy, p. 100. ; Sung, C.Y.; Yi.; YJ, Li. 2013. Imprevious Surface Regulation and Urban Sprawl as Its Unintended Consequence. Land Use Policy. 32: 317-323.

6 Burstein, P. 2003. The Impact of Public Opinion on Public Policy: A Review and an Agenda. Political Research Quarterly. 56(1): 29-40.

7 European Commission. 2008. Attitudes of European Citizens towards the Environment. Special Eurobarometer 295 Report, p. 127. Supra note 1. 
and external influences, as the increase of urban decentralization in the world, capital globalization, neoliberal ideology and western lifestyles. Urban planning authorities did not understand the social, economic and environmental implications of sprawl and failed to respond properly to the challenges raised by the process of suburbanization ${ }^{9}$. Nuissi and Rink ${ }^{10}$ observed that in Eastern Germany, urban sprawl was a product of change in legislation and political environment. In Baltic States, urban sprawl is observed as an important problem, and it is linked to a lack of planning and commercial private interests. This phenomenon started in the second decade after the independence, where agricultural areas were massively converted in residential plots ${ }^{11}$.

In Lithuania, previous research show that the major cities, Vilnius, Klaipeda, Kaunas, Šiauliai, Panevėžys and Alytus, were subject to an intense process of suburbanization, due the high number of licences to build residences and buildings by the municipalities ${ }^{12}$. In Vilnius, the urban sprawl has been observed recently and is related to the expansion of urban areas into the rural surroundings. After the soviet regimen collapse and the free market economy emergence, Vilnius sprawled very fast and without control. From 1990 until 2001, the administrative territory of Vilnius grew by $30 \%$. Since 1990 (the restoration of independence) until 2012, the population of Vilnius decreased by $7 \%$ and increased in the suburban area by $14 \%{ }^{13}$. Figure 1a shows the urban sprawl around Vilnius since 2005. Despite the recognition of urban sprawl impacts in Vilnius city, little is known about the population's perception about the environmental, social and economic implications of it. The aim of this paper is to understand people's views about the impacts of Vilnius urban sprawl.

\section{Materials and methods}

Vilnius is the capital of Lithuania and it is located in the north-eastern Europe at $54^{\circ} 38^{\prime} \mathrm{N}$ and $25^{\circ} 19^{\prime} \mathrm{E}$ (Figure 1b). The city had an area of $401 \mathrm{~km}^{2}$ and a population of 526356 persons in the beginning of $2013^{14}$.

9 Hirt, S.; Stanilov, K. 2009. Twenty Years of Transition: Evolution of Urban Planning in Eastern Europe and the Former Soviet Union, 1989-2009. UN Habitat, Nairobi, Kenya, p. 146.

10 Nuissi, H.; Rink, D. 2005. The 'Production' of Urban Sprawl in Eastern Germany as a Phenomena of Post-Socialist Transformation. Cities. 22(2): 123-134.

11 Cirtautas, M. 2013. Urban Sprawl of Major Cities in the Baltic States. Architecture and Urban Planning. 7: 72-79.

12 Ibid.

13 Ubarevičienè, R.; Burneika, D.; van Ham, M. 2012. Socio-Spatial Transformations, Suburbanization, and Voting Behaviour in the Vilnius Urban Region. IZA Discussion Paper, No.7012, p. 18.

14 Lithuanian Statistics Portal [interactive]. [accessed on 2013-11-03]. <http://www.osp.stat.gov.lt>. 


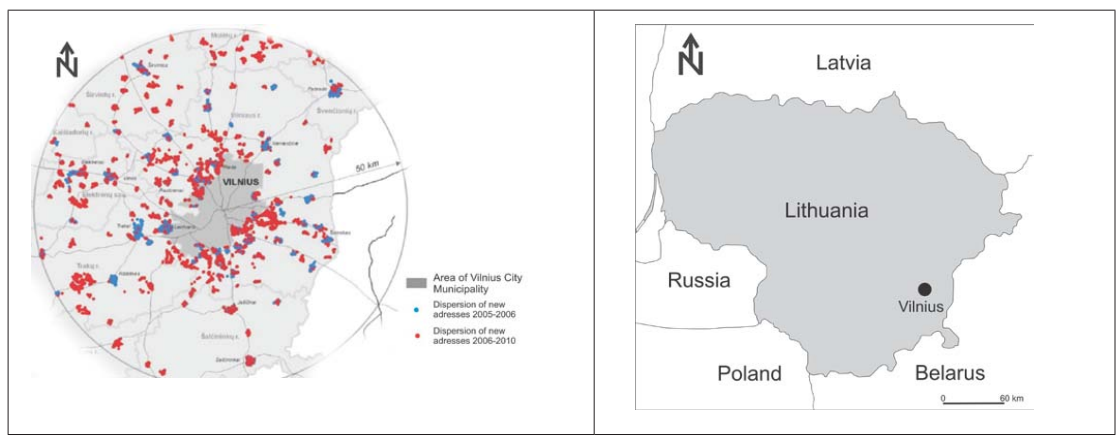

Figure 1a. Urban sprawl in Vilnius region

(Vilnius City Municipality, 2011, in Cirtautas, 2013)

This survey was conducted among the Vilnius population from diverse social and economic conditions. In this preliminary assessment, the authors of this paper interviewed a total of 101 Vilnius inhabitants. A close-ended questionnaire was carried out. In the first two questions ( $1 \mathrm{a}$ and $1 \mathrm{~b}$ ) (Table 1), the interviewed were asked to answer "Yes" or "No", while in the remaining questions they were asked to rate the question, according to their relevance, using a Lickert scale: $1=$ very low; $2=$ low; $3=$ medium; $4=$ high; $5=$ very high. In each component analysed, environmental, socio-economic and stakeholders, an index was calculated. The environmental index (Env_Index) corresponds to the sum of the score attributed by the respondents to the questions $2 \mathrm{a}$ to $2 \mathrm{p}$, socio-economic (SE_Index) - $3 \mathrm{a}$ to $3 \mathrm{f}$, and stakeholders (STK_index) - 4a to 4e. These indexes were calculated to observe the respondent awareness in relation to each sustainable development component and policy needed. The questionnaire was based on a previous survey carried out by the European Union about urban spraw $1^{15}$ (Table 1). The data was analyzed according to the age and profession of the respondents.

Previous to statistical comparison of the data, the normal distribution and heteroscedacity were assessed with the Kolmogorov-Smirnov test and the Levene test, respectively. Data distribution was considered normal at $p<0.05$. The data did not follow the normality and the heteroscedacity, thus, a neperian logarithm (ln) transformation was applied to the data in order to accomplish such requirements. With the transformed data, a one-way ANOVA test was carried out in order to identify differences among age and profession. Significant differences were considered at $p<0.05$. If significant differences were identified, a Tukey HSD posthoc test was applied in order to observe differences within groups. Pearson coefficient

15 Urban sprawl in Europe - The ignored challenge [interactive]. [accessed on 2013-11-01]. http:// www.eea.europa.eu/publications/eea_report_2006_10 
of correlation was computed to identify correlations among the calculated indexes. Significant correlations were considered at $p<0.05$. To identify the degree of correlation among the questions, cluster analysis was carried out, according to the complete linkage amalgamation rule and the distance measure of 1-Pearson $\mathrm{r}$.

\section{Results}

\section{Urban sprawl awareness}

The percentage of the interviewed age was as follows: $18-24-41 \%$; $25-35-23 \%$; $36-50-19 \%$; and $>50-18 \%$. In relation to the profession, $27 \%$ of the respondents were from government (GOV), 41\% from private sector (PS), 6\% from nongovernmental organizations (NGO), $7 \%$ from municipality (SAV) and $20 \%$ were unemployed (UN). Among the respondents, the younger (18-24) were the ones that recognized more that the urban sprawl is a threat in Vilnius (88\%), while the older $(>50)$ respondents gave less importance to the problem (61\%). All municipality and NGO workers considered urban sprawl a threat to Vilnius, whereas only $70 \%$ of government workers assumed it to be a problem (Figure 2a). The interviewed aged between 35-50 years answered that there was no national measures to limit the urban sprawl, while the older respondents (67\%) thought that there was no need of additional measures. The majority of the government and municipality members thought that there was a lack of measures to reduce the urban sprawl, $85 \%$ and $86 \%$, respectively. Only $66 \%$ of NGO workers thought that there was a lack of measures to limit the urban expansion (Figure $2 \mathrm{~b}$ ).

Table 1. Questions considered in this survey (modified from EEA, 2006 ${ }^{16}$ )

\begin{tabular}{|l|l|}
\hline Question & \\
\hline $1 \mathrm{a}$ & Is urban sprawl considered as a threat in your country/region/municipalities? \\
\hline $1 \mathrm{~b}$ & Are there dedicated national/regional/local measures to limit urban sprawl? \\
\hline Loss of environmental resources \\
\hline $2 \mathrm{a}$ & Consumption of land and soil \\
\hline $2 \mathrm{~b}$ & Consumption of concrete and other building materials \\
\hline $2 \mathrm{c}$ & Expansion of quarries near to nature reserves \\
\hline $2 \mathrm{~d}$ & Over extraction of gravel from river beds or ridges \\
\hline $2 \mathrm{e}$ & Loss of soil permeability \\
\hline Efficiency of compact urban areas vs. sprawled areas \\
\hline $2 \mathrm{f}$ & Growing consumption of energy \\
\hline
\end{tabular}




\begin{tabular}{|c|c|}
\hline $2 \mathrm{~g}$ & Growth in $\mathrm{CO}_{2}$ emissions \\
\hline $2 \mathrm{~h}$ & Growing consumption of water \\
\hline \multicolumn{2}{|c|}{ Natural, protected areas and rural environments } \\
\hline $2 \mathrm{i}$ & Loss of natural habitats \\
\hline $2 \mathrm{j}$ & Loss of best agricultural land \\
\hline $2 \mathrm{k}$ & Increase in the use of water and fertilizer in less productive areas \\
\hline 21 & More noise in rural areas \\
\hline \multicolumn{2}{|c|}{ The quality of urban life and health } \\
\hline $2 \mathrm{~m}$ & Increase in air pollution \\
\hline $2 \mathrm{n}$ & High noise level \\
\hline 20 & Traffic congestion \\
\hline $2 \mathrm{p}$ & Vulnerability of suburbs to minor geo-hazards \\
\hline \multicolumn{2}{|c|}{ Social impacts } \\
\hline $3 \mathrm{a}$ & Exacerbation of social and economic division \\
\hline $3 \mathrm{~b}$ & Segregation of residential areas \\
\hline $3 c$ & Less social interaction \\
\hline \multicolumn{2}{|c|}{ Economic impacts } \\
\hline $3 \mathrm{~d}$ & $\begin{array}{l}\text { Increased household expenditure on commuting from home to work over } \\
\text { longer and longer distances }\end{array}$ \\
\hline $3 e$ & $\begin{array}{l}\text { The cost of the congestion for business in sprawling urban areas with inefficient } \\
\text { transportation systems }\end{array}$ \\
\hline $3 f$ & Suboptimal use of abandoned industrial areas (brownfields) \\
\hline $3 g$ & No savings in the provision of water and sewage facilities \\
\hline \multicolumn{2}{|c|}{ Local stakeholders measures } \\
\hline $4 \mathrm{a}$ & $\begin{array}{l}\text { Development of long term integrated plans promoting sustainable development } \\
\text { and the limitation of urban sprawl }\end{array}$ \\
\hline $4 \mathrm{~b}$ & $\begin{array}{l}\text { Policies for the re-use of derelict brownfield sites and renovation of public } \\
\text { spaces to assist in the creation of more compact urban forms }\end{array}$ \\
\hline $4 \mathrm{c}$ & $\begin{array}{l}\text { Policies for avoiding the use of greenfield sites and complementary urban } \\
\text { containment policies }\end{array}$ \\
\hline $4 \mathrm{~d}$ & $\begin{array}{l}\text { Identification of the key partners, including the private sector and community, } \\
\text { as well as local, regional and national government and their mobilisation in the } \\
\text { planning, implementation and evaluation of urban development }\end{array}$ \\
\hline $4 \mathrm{e}$ & $\begin{array}{l}\text { Management of the urban-rural interactions via cooperation and coordination } \\
\text { between urban authorities and rural and regional authorities in promoting } \\
\text { sustainable development }\end{array}$ \\
\hline
\end{tabular}




\section{Urban sprawl effects in the environment}

The majority of the interviewed thought that urban sprawl has a medium impact (29\%) in land and soil consumption. However, the respondents considered contribution to a high and very high consumption of concrete and other building materials, and it is a threat to protected areas. The great part of the respondents thought that urban sprawl has a medium impact (47\%) in the extraction of gravel from river beds or ridges, and assumed that it has a high impact (36\%) in the loss of soil permeability (Figure 3a). According to the majority of the interviewed, the urban expansion has a high impact in the energy consumption, $\mathrm{CO}_{2}$ emissions and water consumption (Figure $3 \mathrm{~b}$ ). The great part also argued that the urban expansion has a medium impact in the loss of natural habitats and the best agricultural land, and a high impact on the use of fertilizers in less productive areas and in the noise increase in rural areas (Figure 3c). The majority of the respondents believed that urban sprawl increases the levels of air pollution, noise and traffic congestion and defended that it has a medium impact in the vulnerability to geo-hazards (Figure 3c).

According to the age of the interviewed, significant differences in the question $2 \mathrm{~m}$ (increase in air pollution) were identified. The younger respondents thought that it has a higher impact than the older ones did (Table 1). In relation to the professions of the interviewed, significant differences in the question $2 c$ (expansion of quarries near to natural reserves), $3 \mathrm{n}$ (high noise level) and $2 \mathrm{o}$ (traffic congestion) were observed. Government employees assumed that urban sprawl represents a higher threat to natural areas, high noise level and traffic congestion than the unemployed ones did. On average, the respondents rated high the questions $2 \mathrm{~m}$ (increase in air pollution) and 20 (traffic congestion), with a score of 4.13 and 4.14, respectively, and they rated less the question $2 \mathrm{a}$ (consumption of land and soil) and $2 \mathrm{~d}$ (over extraction of gravel from river beds or ridges) with a score of 2.88 and 2.61 , respectively.

\section{Urban sprawl socio-economic impacts}

The majority of the respondents answered that urban sprawl induces a medium impact in exacerbation of social and economic division and a high impact on segregation of residential areas and less social interaction (Figure 4a). They also assumed that urban expansion has high impacts in the increased household expenditure on commuting from home to work over longer and longer distances, cost of the congestion for business in sprawled urban areas with inefficient transportation systems, suboptimal use of abandoned industrial areas and no savings in the provision of water and sewage facilities (Figure $4 \mathrm{~b}$ ).

Significant differences among age classes in the questions 3a (exacerbation of social and economic division), $3 \mathrm{~b}$ (segregation of residential areas) and $3 \mathrm{~g}$ (no savings in the provision of water and sewage facilities) were identified. Older respondents rated significantly high the impact of urban sprawl in the latter three questions than 
the younger ones did. Significant differences were observed among professions in the question $3 \mathrm{~b}$ (segregation of residential areas). Government, NGO, private sector and municipal workers rated significantly high the question $3 \mathrm{~b}$ than the unemployed ones did (Table 3). In relation to economic questions, significant differences among age classes in the question $3 \mathrm{~d}$ (increased household expenditure on commuting from home to work over longer and longer distances) were observed. Younger respondents rated significantly high this question than the older ones did. Also, significant differences were identified in SE-Index. Government, NGO, private sector and municipal workers rated significantly high the socio-environmental questions than the unemployed respondents did (Table 3). On average, the interviewed rated higher the question $3 \mathrm{f}$ (suboptimal use of abandoned industrial areas), with a score of 3.77, and less the question 3a (exacerbation of social and economic division), with a score of 3.18 (Table 3 ).

a

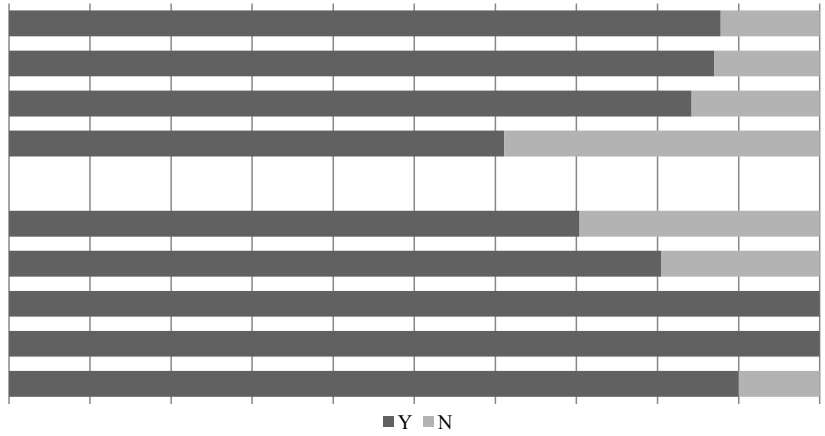

b

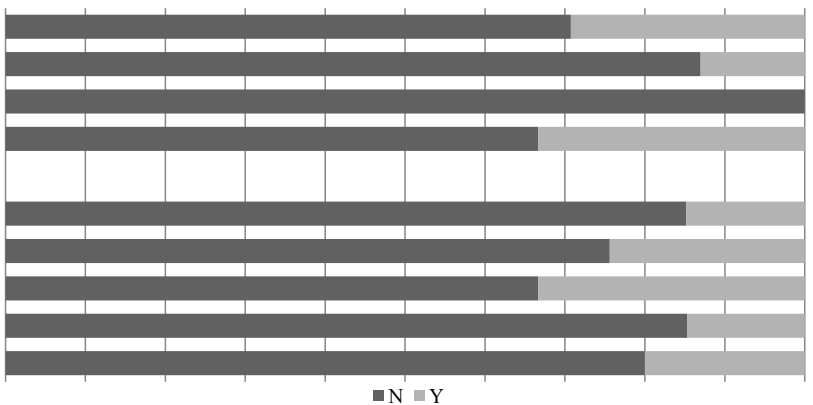

Figure 2. Releative percentage of the answers to the question a) Is urban sprawl considered as a threat in your country/region/municipalities? and

b) Are there dedicated national/regional/local measures to limit urban sprawl? 
a

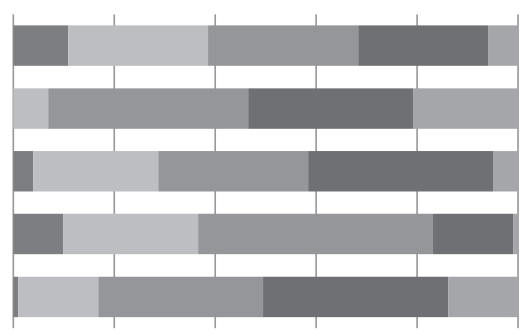

c

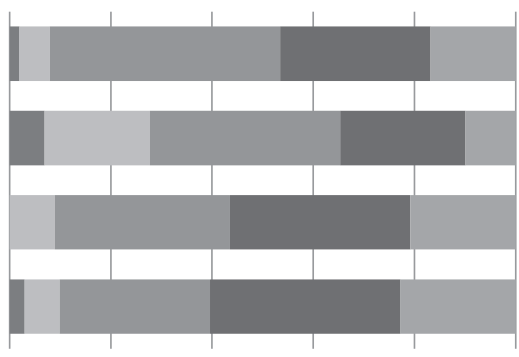

b

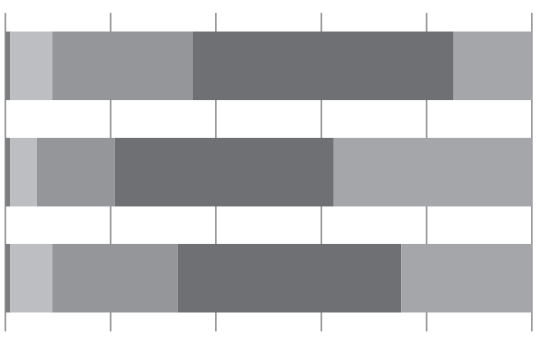

d

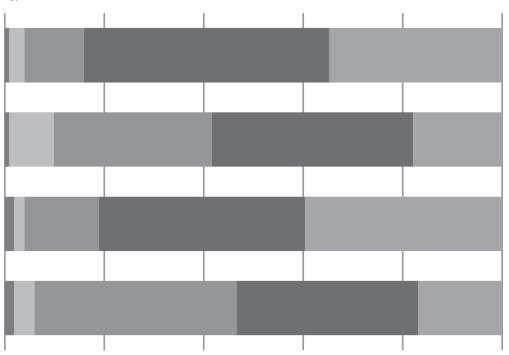

Very low Low $\quad$ Medium $\quad$ High $\quad$ Very high

Figure 3. Relative percentage of the answers to the impact of urban sprawl in a) Loss of environmental resources, b) Efficiency of compact urban areas vs sprawled areas, c) Natural, protected areas and rural environments, and d) Quality of urban life and health in Vilnius

Table 2. Urban sprawl environmental impacts according to the age and profession of the participants on a) Consumption of land and soil, b) Consumption of concrete and other building materials, c) Expansion of quarries near to natural reserves, d) Over extraction of gravel from river beds or ridges, e) Loss of soil permeability, f) Growing consumption of energy, g) Growth in $\mathrm{CO}_{2}$ emissions, h) Growing consumption of water, i) Loss of natural habitats, $j$ ) Loss of best agricultural land, k) Increase in the use of water and fertiliser in less productive areas, l) More noise in rural areas, m) Increase in air pollution, n) High noise level, o) Traffic congestion, p) Vulnerability of suburbs to minor geo-hazards, and Environmental Index (Env_Index). Significant differences were considered at $p<0.05$. Government (GOV), private sector (PS), nongovernmental organization (NGO), municipality (SAV) and the unemployed (UN). 


\begin{tabular}{|c|c|c|c|c|c|c|c|c|}
\hline $\begin{array}{c}\text { Ques- } \\
\text { tion }\end{array}$ & F & Age & Mean & $\mathrm{SD}$ & F & $\begin{array}{l}\text { Pro- } \\
\text { fession }\end{array}$ & Mean & SD \\
\hline \multirow[t]{6}{*}{$2 \mathrm{a}$} & \multirow[t]{6}{*}{$\mathrm{F}=1.69, \mathrm{n} . \mathrm{s}$} & $18-24$ & 2.95 & 1.22 & \multirow{5}{*}{$\mathrm{F}=2.12, \mathrm{n} . \mathrm{s}$} & GOV & 3 & 0.78 \\
\hline & & $25-35$ & 2.47 & 1.03 & & PS & 2.58 & 1.13 \\
\hline & & $36-50$ & 3.21 & 0.91 & & NGO & 3.83 & 0.75 \\
\hline & & \multirow[t]{2}{*}{$>50$} & \multirow[t]{2}{*}{2.88} & \multirow[t]{2}{*}{0.98} & & SAV & 3 & 1 \\
\hline & & & & & & UN & 3 & 1.33 \\
\hline & & All & 2.88 & 1.09 & & & & \\
\hline \multirow{6}{*}{$2 \mathrm{~b}$} & \multirow{6}{*}{$\mathrm{F}=0.35$, n.s } & $18-24$ & 2.78 & 0.93 & \multirow{5}{*}{$\mathrm{F}=0.99, \mathrm{n} . \mathrm{s}$} & GOV & 3.92 & 0.87 \\
\hline & & $25-35$ & 3.56 & 0.94 & & PS & 3.63 & 0.82 \\
\hline & & $36-50$ & 3.63 & 0.83 & & NGO & 3.5 & 0.83 \\
\hline & & $>50$ & 3.61 & 0.77 & & SAV & 3.28 & 0.48 \\
\hline & & & & & & UN & 3.6 & 1.09 \\
\hline & & All & 3.67 & 0.88 & & & & \\
\hline \multirow{6}{*}{$2 c$} & \multirow{6}{*}{$\mathrm{F}=0.34, \mathrm{n} . \mathrm{s}$} & $18-24$ & 3.02 & 1.06 & \multirow{5}{*}{$\begin{array}{l}F=2.66 \\
p<0.05\end{array}$} & GOV & $3.62 \mathrm{a}$ & 0.88 \\
\hline & & 25-35 & 3.17 & 0.88 & & PS & $2.92 \mathrm{~b}$ & 0.95 \\
\hline & & $\begin{array}{c}36-50 \\
>50\end{array}$ & $\begin{array}{l}3.21 \\
3.27\end{array}$ & $\begin{array}{l}0.91 \\
1.01\end{array}$ & & NGO & $3.16 \mathrm{ab}$ & 0.98 \\
\hline & & & & & & SAV & $3.14 \mathrm{ab}$ & 0.89 \\
\hline & & & & & & UN & $2.9 \mathrm{~b}$ & 1.02 \\
\hline & & All & 3.13 & 0.98 & & & & \\
\hline \multirow{6}{*}{$2 d$} & \multirow{6}{*}{$\mathrm{F}=0.23, \mathrm{n} . \mathrm{s}$} & $18-24$ & 2.68 & 1.01 & \multirow{5}{*}{$\mathrm{F}=0.50, \mathrm{n} . \mathrm{s}$} & GOV & 2.77 & 1.02 \\
\hline & & $25-35$ & $\begin{array}{l}2.73 \\
2.84\end{array}$ & $\begin{array}{l}0.75 \\
0.83\end{array}$ & & PS & 2.70 & 0.87 \\
\hline & & $36-50$ & $\begin{array}{l}.84 \\
2.61\end{array}$ & $\begin{array}{l}0.83 \\
0.84\end{array}$ & & NGO & 2.33 & 1.03 \\
\hline & & $>50$ & & & & SAV & 3 & 0.81 \\
\hline & & & & & & UN & 2.65 & 0.74 \\
\hline & & All & 2.71 & 0.88 & & & & \\
\hline \multirow{6}{*}{$2 \mathrm{e}$} & \multirow{6}{*}{$\mathrm{F}=0.54, \mathrm{n} . \mathrm{s}$} & $18-24$ & 3.46 & 1.02 & \multirow{5}{*}{$\mathrm{F}=1.70, \mathrm{n} . \mathrm{s}$} & GOV & 3.81 & 1.01 \\
\hline & & $25-35$ & 3.30 & 0.87 & & PS & 3.31 & 0.96 \\
\hline & & $36-50$ & 3.68 & 0.82 & & NGO & 3.5 & 0.83 \\
\hline & & $>50$ & 3.44 & 0.78 & & SAV & 3.71 & 0.75 \\
\hline & & & & & & UN & 3.2 & 0.89 \\
\hline & & All & 3.46 & 0.95 & & & & \\
\hline \multirow{6}{*}{$2 f$} & \multirow{6}{*}{$\mathrm{F}=0.12, \mathrm{n} . \mathrm{s}$} & $18-24$ & 3.82 & 0.89 & \multirow{5}{*}{$\mathrm{F}=0.47, \mathrm{n} . \mathrm{s}$} & GOV & 3.66 & 1.03 \\
\hline & & $25-35$ & 3.73 & 0.75 & & PS & 3.75 & 0.83 \\
\hline & & $36-50$ & 3.57 & 0.96 & & NGO & 3.66 & 0.51 \\
\hline & & $>50$ & 3.44 & 0.78 & & SAV & 3.28 & 0.75 \\
\hline & & & & & & UN & 3.75 & 0.78 \\
\hline & & All & 3.69 & 0.85 & & & & \\
\hline
\end{tabular}


Paulo Pereira, Algirdas Monkevičius, Hanna Siarova. Public Perception of Environmental, Social and...

\begin{tabular}{|c|c|c|c|c|c|c|c|c|}
\hline \multirow{6}{*}{$2 \mathrm{~g}$} & \multirow{6}{*}{$\mathrm{F}=0.38, \mathrm{n} . \mathrm{s}$} & $18-24$ & 4.04 & 0.94 & \multirow{5}{*}{$\mathrm{F}=1.63, \mathrm{n} . \mathrm{s}$} & GOV & 4.41 & 0.79 \\
\hline & & $25-35$ & 4.13 & 0.81 & & PS & 4.04 & 0.94 \\
\hline & & $36-50$ & 4.26 & 0.73 & & NGO & 4.16 & 0.75 \\
\hline & & \multirow[t]{2}{*}{$>50$} & \multirow[t]{2}{*}{4} & \multirow[t]{2}{*}{1.08} & & SAV & 4.14 & 0.69 \\
\hline & & & & & & UN & 3.75 & 0.96 \\
\hline & & All & 4.09 & 0.90 & & & & \\
\hline \multirow{6}{*}{$2 \mathrm{~h}$} & \multirow{6}{*}{$\mathrm{F}=0.49, \mathrm{n} . \mathrm{s}$} & $18-24$ & 3.92 & 0.87 & \multirow{5}{*}{$\mathrm{F}=1.95, \mathrm{n} . \mathrm{s}$} & GOV & 4.18 & 0.87 \\
\hline & & $25-35$ & $\begin{array}{l}3.78 \\
3.84\end{array}$ & $\begin{array}{l}0.90 \\
1.01\end{array}$ & & PS & 3.73 & 0.89 \\
\hline & & $36-50$ & 3.61 & 1.03 & & NGO & 3.33 & 1.50 \\
\hline & & \multirow[t]{2}{*}{$>50$} & & & & SAV & 4 & 0.57 \\
\hline & & & & & & UN & 3.60 & 0.88 \\
\hline & & All & 3.82 & 0.93 & & & & \\
\hline \multirow{6}{*}{$2 \mathrm{i}$} & \multirow{6}{*}{$\mathrm{F}=1.44, \mathrm{n} . \mathrm{s}$} & $18-24$ & 3.65 & 1.02 & \multirow{5}{*}{$\mathrm{F}=1.09, \mathrm{n} . \mathrm{s}$} & GOV & 3.70 & 0.95 \\
\hline & & $25-35$ & 3.47 & 0.66 & & PS & 3.39 & 0.83 \\
\hline & & $36-50$ & 3.68 & 0.94 & & NGO & 3.50 & 1.22 \\
\hline & & $>50$ & 3.16 & 0.85 & & SAV & 3.14 & 0.37 \\
\hline & & & & & & UN & 3.75 & 1.01 \\
\hline & & All & 3.53 & 0.91 & & & & \\
\hline \multirow{6}{*}{$2 j$} & \multirow{6}{*}{$\mathrm{F}=1.33, \mathrm{n} . \mathrm{s}$} & $18-24$ & 3.65 & 1.01 & \multirow{5}{*}{$\mathrm{F}=1.07, \mathrm{n} . \mathrm{s}$} & GOV & 3.33 & 1.17 \\
\hline & & $25-35$ & 3.08 & 0.84 & & PS & 2.85 & 0.93 \\
\hline & & $36-50$ & 3.26 & 1.04 & & NGO & 3.16 & 0.75 \\
\hline & & $>50$ & 2.66 & 1.13 & & SAV & 3 & 1 \\
\hline & & & & & & UN & 3 & 1.22 \\
\hline & & All & 3.53 & 0.91 & & & & \\
\hline \multirow{6}{*}{$2 \mathrm{k}$} & \multirow{6}{*}{$\mathrm{F}=0.15, \mathrm{n} . \mathrm{s}$} & $18-24$ & 3.70 & 0.95 & \multirow{5}{*}{$\mathrm{F}=0.75, \mathrm{n} . \mathrm{s}$} & GOV & 3.85 & 1.10 \\
\hline & & 25-35 & 3.73 & 0.91 & & PS & 3.58 & 0.77 \\
\hline & & $\begin{array}{c}36-50 \\
>50\end{array}$ & $\begin{array}{l}3.68 \\
3.55\end{array}$ & $\begin{array}{l}0.88 \\
0.85\end{array}$ & & NGO & 3.83 & 0.98 \\
\hline & & & & & & SAV & 3.28 & 0.48 \\
\hline & & & & & & UN & 3.75 & 0.96 \\
\hline & & All & 3.68 & 0.90 & & & & \\
\hline \multirow{6}{*}{21} & \multirow{6}{*}{$\mathrm{F}=0.29, \mathrm{n} . \mathrm{s}$} & $18-24$ & 3.75 & 1.13 & \multirow{5}{*}{$\mathrm{F}=0.72, \mathrm{n} . \mathrm{s}$} & GOV & 3.85 & 0.81 \\
\hline & & $25-35$ & 3.73 & 0.86 & & PS & 3.58 & 1.07 \\
\hline & & $36-50$ & 3.73 & 0.91 & & NGO & 3.83 & 0.75 \\
\hline & & $>50$ & 3.50 & 0.85 & & SAV & 3.28 & 1.11 \\
\hline & & & & & & UN & 3.85 & 1.09 \\
\hline & & All & 3.70 & 0.99 & & & & \\
\hline
\end{tabular}




\begin{tabular}{|c|c|c|c|c|c|c|c|c|}
\hline $\begin{array}{l}\text { Ques- } \\
\text { tion }\end{array}$ & F & Age & Mean & SD & F & $\begin{array}{c}\text { Pro- } \\
\text { fession }\end{array}$ & Mean & SD \\
\hline \multirow{6}{*}{$2 \mathrm{~m}$} & \multirow{6}{*}{$\begin{array}{l}\mathrm{F}=2.70 \\
p<0.05\end{array}$} & $18-24$ & $4.29 \mathrm{a}$ & 0.84 & \multirow{5}{*}{$\mathrm{F}=0.43, \mathrm{n} . \mathrm{s}$} & GOV & 4.14 & 0.94 \\
\hline & & $25-35$ & $4.04 \mathrm{bc}$ & 0.76 & & PS & 4.14 & 0.65 \\
\hline & & $36-50$ & $4.31 \mathrm{a}$ & 0.67 & & NGO & 4.50 & 0.54 \\
\hline & & $>50$ & $3.72 c$ & 0.82 & & SAV & 4.14 & 0.69 \\
\hline & & & & & & UN & 4 & 1.02 \\
\hline & & All & 4.13 & 0.81 & & & & \\
\hline \multirow{6}{*}{$2 n$} & \multirow{6}{*}{$\mathrm{F}=1.32, \mathrm{n} . \mathrm{s}$} & $18-24$ & 3.51 & 1.01 & \multirow{5}{*}{$\begin{array}{l}F=2.95 \\
p<0.05\end{array}$} & GOV & $4.07 \mathrm{a}$ & 0.91 \\
\hline & & $25-35$ & 3.78 & 0.85 & & PS & $3.63 \mathrm{ab}$ & 0.82 \\
\hline & & $36-50$ & 3.94 & 0.84 & & NGO & $3.50 \mathrm{ab}$ & 1.04 \\
\hline & & $>50$ & 3.50 & 0.78 & & SAV & $3.57 \mathrm{ab}$ & 0.53 \\
\hline & & & & & & UN & $3.20 \mathrm{~b}$ & 0.95 \\
\hline & & All & 3.65 & 0.91 & & & & \\
\hline \multirow{6}{*}{20} & \multirow{6}{*}{$\mathrm{F}=0.47, \mathrm{n} . \mathrm{s}$} & $18-24$ & 4.09 & 0.92 & \multirow{5}{*}{$\begin{array}{l}\mathrm{F}=2.20 \\
p<0.05\end{array}$} & GOV & $4.44 \mathrm{a}$ & 0.75 \\
\hline & & $25-35$ & 4.21 & 1.09 & & PS & $4.17 \mathrm{a}$ & 0.86 \\
\hline & & $\begin{array}{c}36-50 \\
>50\end{array}$ & $\begin{array}{c}4.31 \\
4\end{array}$ & $\begin{array}{l}0.74 \\
0.68\end{array}$ & & $\mathrm{NGO}$ & $4.33 \mathrm{a}$ & $\begin{array}{l}0.00 \\
0.81\end{array}$ \\
\hline & & & & & & SAV & $3.71 \mathrm{~b}$ & 0.48 \\
\hline & & & & & & UN & $3.80 \mathrm{~b}$ & 1.10 \\
\hline & & All & 4.14 & 0.88 & & & & \\
\hline \multirow{6}{*}{$2 \mathrm{p}$} & \multirow{6}{*}{$\mathrm{F}=1.95, \mathrm{n} . \mathrm{s}$} & $18-24$ & 3.56 & 1.04 & \multirow{5}{*}{$\mathrm{F}=1.61, \mathrm{n} . \mathrm{s}$} & GOV & 4.44 & 0.75 \\
\hline & & $25-35$ & 3.47 & 0.73 & & PS & 4.17 & 0.86 \\
\hline & & $36-50$ & 4.05 & 0.70 & & NGO & 4.33 & 0.81 \\
\hline & & $>50$ & 3.50 & 0.70 & & SAV & 3.71 & 0.48 \\
\hline & & & & & & UN & 3.80 & 1.10 \\
\hline & & All & 3.62 & 0.88 & & & & \\
\hline \multirow{6}{*}{$\begin{array}{l}\text { Env- } \\
\text { Index }\end{array}$} & \multirow{6}{*}{$\mathrm{F}=1.02, \mathrm{n} . \mathrm{s}$} & $18-24$ & 57.51 & 8.06 & \multirow{5}{*}{$\mathrm{F}=1.52, \mathrm{n} . \mathrm{s}$} & GOV & 60.51 & 10.83 \\
\hline & & $25-35$ & 56.47 & 8.26 & & PS & 55.87 & 7.58 \\
\hline & & $36-50$ & 59.26 & 9.42 & & NGO & 57.33 & 3.61 \\
\hline & & $>50$ & 54.5 & 9.30 & & SAV & 55.28 & 6.72 \\
\hline & & & & & & UN & 55.40 & 6.72 \\
\hline & & All & 57.06 & 8.60 & & & & \\
\hline
\end{tabular}

Local stakeholders responses to urban sprawl

The majority of the respondents answered that the questions raised had very high priority (Figure 5). According to the age classes, significant differences were identified in the questions $4 \mathrm{a}$ (development of long term integrated plans promoting sustainable development and the limitation of urban sprawl) and $4 \mathrm{~b}$ (policies for the 
re-use of derelict brownfield sites and renovation of public spaces to assist in the creation of more compact urban forms). Older respondents rated significantly higher these questions than the younger ones did. No significant differences were identified among profession in any of the questions (Table 4). On average, the respondents rated higher the questions $4 \mathrm{c}$ (policies for avoiding the use of greenfield sites and complementary urban containment policies) and $4 \mathrm{e}$ (management of the urbanrural interactions via cooperation and coordination between urban authorities and rural and regional authorities in promoting sustainable development), with a score of 4.15 , and less the question $4 \mathrm{a}$ (development of long term integrated plans promoting sustainable development and the limitation of urban sprawl), with a score of 4.05.

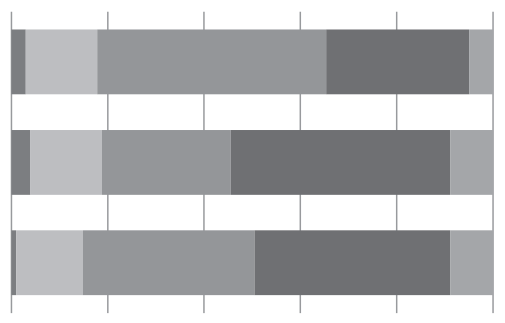

b

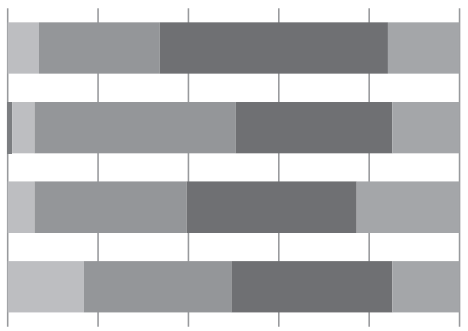

-Very low Low $\quad$ Medium $\quad$ High $\quad$ Very high

Figure 4. Relative percentage of the answers to the impact of urban sprawl in a) society and b) economy in Vilnius

\section{Relation among variables}

The correlation between Env-Index and SE-Index was 0.68, $p<0.001$, between Env-Index and STK-Index was 0.21, $p<0.05$, and between SE-Index and STK-Index was $0.35, p<0.001$. The cluster analysis identified 4 different groups. The cut line was applied at the 0.91 linkage distance, because this was the distance at this the majority of the variables were clustered. The first group was composed of the questions $4 \mathrm{~d}$, $4 \mathrm{c}, 4 \mathrm{~b}, 4 \mathrm{e}$ and $4 \mathrm{a}$, the second group consisted of the questions $3 \mathrm{a}, 3 \mathrm{~b}, 3 \mathrm{~g}, 3 \mathrm{f}, 3 \mathrm{c}, 2 \mathrm{p}$, $2 \mathrm{l}$ and $2 \mathrm{p}$, the third group was composed of the questions $2 \mathrm{l}, 2 \mathrm{k}, 2 \mathrm{~d}, 2 \mathrm{e}$ and $2 \mathrm{c}$, and the fourth group included the questions $3 \mathrm{~d}, 2 \mathrm{j}, 2 \mathrm{i}, 2 \mathrm{~m}, 2 \mathrm{~h}, 2 \mathrm{~g}, 2 \mathrm{o}, 3 \mathrm{e}, 2 \mathrm{n}, 2 \mathrm{f}, 2 \mathrm{~b}$ and 2a (Figure 5).

\section{Discussion}

\section{Urban sprawl awareness}

Urban sprawl, as it was assumed by the respondents, is an important problem in Vilnius and people claimed to take more measures to reduce it. The perception of urban 
sprawl is higher among young respondents and workers in NGO and municipalities, while the perception about the lack of regulation is higher in the group of 36-50 year olds and among government and municipal workers. These results suggest that the young generation is more aware about the urban sprawl problem in Vilnius and the older is demanding for more regulations. Among professions, municipal workers seem to have a higher perception of urban sprawl than the others, since they might be more in contact with the problem. Previous studies in Europe defined clearly that urban sprawl is a priority in police agenda, and it affects importantly many European cities ${ }^{17}$. In Vilnius, urban sprawl is assumed to be a problem, which has increased very fast in the recent years ${ }^{18}$, driven also by the arterial roads that connect Vilnius to Kaunas, to Panevėžys, to Marijampolè and to Belarussian border (Lida and Minsk) ${ }^{19}$. This uncontrolled expansion attributed to the lack of sustainable planning and more realistic demographic previsions at municipal scale and measures to control the urban sprawl ${ }^{20}$, as it was also confirmed by the interviewed. The causes of the urban sprawl in Vilnius are the high costs of soil in the city centre and lower prices in the suburban areas, the population lifestyle that values living in a house with a private yard and surroundings and the opportunity to buy second or third residence ${ }^{21}$.

\section{Urban sprawl effects in the environment}

The majority of the respondents assume that urban sprawl has medium impacts in land and soil consumption, the extraction of gravel from river beds or ridges, loss of natural habitats and the best agricultural land and vulnerability to geo-hazards. In the remaining questions, consumption of concrete and other building materials, threat to protected areas, energy consumption, $\mathrm{CO}_{2}$ emissions and consumption of

17 Kasanko, M.; Barredo, J.I.; Lavalle, C.; McCormick, N.; Demicheli, L.; Sagris, V.; Brezger, A. 2006. Are European Cities Becoming Dispersed? A Comparative Analysis of 15 European Urban Areas. Landscape and Urban Planning. 77(1-2): 111-130.; Catalan, B.; Sauri, D.; Serra, P. 2008. Urban Sprawl in the Mediterranean: Patterns of Growth and Change in the Barcelona Metropolitan Region. Landscape and Urban Planning. 85(3-4): 174-184.; Schwarz, N. 2010. Urban Form Revisited - Selecting Indicators for Characterising European Cities. Landscape and Urban Planning. 96(1): 29-47.; Arribas-Bel, D.; Nijkamp, P.; Scholten, H. 2011. Multidimensional Urban Sprawl in Europe: A Self-Organizing Map Approach. Computers, Environment and Urban Systems. 35(4): 263-275.

18 Burneika, D.; Ubarevičiené, R. 2011. The Sprawl of Vilnius City - Some Consequences of Rural-Urban Transformations. Annales Geographicae. 43-44: 108-115.

19 Matijošaitienè, I.; Stankevičè, I. 2011. Hendonomic Roadscapes in the Context of Urban Sprawl. Architecture and Urban Planning. 5: 70-76.

20 Bardauskienè, D.; Pakalnis, M. 2012. Foresighted Urban Planning. Environmental Research, Engineering and Management. 1(59): 63-72.

21 Bardauskiene, D.; Pakalnis, M. 2011. Current Trends and Management of Urban Development in Lithuania. Proceedings Real Corp 2011, Change for Stability: Lifecycles of Cities and Regions. Tagusband: p. 139-144. 
water, use of fertilizers in less productive areas and noise increase in rural areas, traffic and air pollution were mostly rated as having a high impact. This evaluation shows that the respondents value more aspects related with the consumption, pollution and nature protection rather than soil degradation and nature resources depletion. The primary impact and the most relevant of the urban sprawl is the consumption of land, soil and non-renewable resources and change of agricultural use to urban use. These changes are permanent and can only be reversible after a high investment ${ }^{22}$. The most relevant aspects of the urban sprawl were less rated by the respondents. Soil sealing and impermeabilization reduce soil ecological functions, groundwater recharge and increase the runoff and the vulnerability to natural hazards, as flash floods $\mathrm{s}^{23}$ that normally have important impacts in human goods and lives ${ }^{24}$. In the context of climate change, where an increase of flash flood in many eastern European cities is expected ${ }^{25}$, it is important to raise more awareness about the problem. Lithuania is considered a country with medium flood risk ${ }^{26}$. Recent studies have shown that in general spring river floods in Lithuanian rivers are coming earlier and there is a decreasing trend in their magnitude ${ }^{27}$. However, specific spatial patterns are observed in Lithuanian territory. In the western part, there is a positive trend of the maximum discharges, while in the middle and the south-eastern parts there is a decrease $^{28}$. In Vilnius region, there is a reduction in the snow melting floods and this may influence public perception. River flood projections show that river runoff is expected to decrease in the future ${ }^{29}$.

22 Supra note 1.

23 Scalenghe, R.; Marsan, F.A. 2009. The Anthropogenic Sealing of Soils in Urban Areas. Landscape and Urban Planning. 90(1-2): 1-10.; Yang, J.L.; Zhang, G.L. 2011. Water Infiltration in Urban Soils and Its Effects on the Quantity and Quality of Runoff. Journal of Soils and Sediments. 11(5): 751-761.; Depietri, Y.; Renaud, F.G.; Kallis, G. 2012. Heat Waves and Floods in Urban Areas: A Policy-Oriented Review of Ecosystems Services. Sustainability Science. 7(1): 95-107.

24 Einfalt, T.; Hatzfeld, F.; Wagner, A.; Seltmann, J.; Castro, D.; Frerichs, S. 2009. URBAS: Forecasting and Management of Flash Floods in Urban Areas. Urban Water Journal. 6(5): 369-374.

25 EEA. 2012a. Urban Adaptation to Climate Change in Europe. Challenges and Opportunities for Cities Together with Supportive National and European Policies. European Environmental Agency Report. 2: 143.

26 Jelinek, R.; Wood, M.; Hervas, J. 2007. Risk Mapping of Flood Hazards in New Member States. Join Research Center. Institute for the Protection and Security of the Citizen, p. 37.

27 Martinkova, M. 2013. A Review of Applied Methods in Europe for Flood Frequency Analysis in a Changing Environment: Floodfreq COST Action ES0901: European Flood Frequency Estimation. Centre for Ecology and Hydrology, University of Bath, p. 170.

28 Meilutyte-Barauskienè, D.; Kovalenkoviené, M. 2007. Change of Spring Flood Parameters in Lithuanian Rivers. Energetika. 53(2): 26-33.

29 Kriaučiūnienè, J.; Jakimavičius, D.; Sarauskienè, D.; Kaliatka, T. 2013. Estimation of Uncertainty Sources in the Projections of Lithuanian River Runoff. Stochastic Environmental Research and Risk Assessment. 27(4): 769-784. 
Table 3. Urban sprawl socio-economic impacts, according to the age and profession of the participants. a) Social, b) economic impacts, and c) socio-economic index (SE_Index). Significant differences were considered at $p<0.05$. Governement (GOV), private sector (PS), non-governmental organization (NGO), municipality (SAV) and the unemployed (UN).

\begin{tabular}{|c|c|c|c|c|c|c|c|c|}
\hline $\begin{array}{l}\text { Ques- } \\
\text { tion }\end{array}$ & F & Age & Mean & SD & $\mathrm{F}$ & $\begin{array}{l}\text { Profes- } \\
\text { sion }\end{array}$ & Mean & SD \\
\hline \multirow[t]{6}{*}{$3 a$} & $\begin{array}{l}F=2.60 \\
p<0.05\end{array}$ & $18-24$ & $2.92 \mathrm{~b}$ & 0.95 & \multirow{5}{*}{$\mathrm{F}=0.47, \mathrm{n} . \mathrm{s}$} & GOV & 3.44 & 0.75 \\
\hline & & $25-35$ & $3.47 \mathrm{a}$ & 0.79 & & PS & 3.29 & 0.67 \\
\hline & & $36-50$ & $3.21 \mathrm{a}$ & 0.71 & & NGO & 2.50 & 0.54 \\
\hline & & $>50$ & $3.38 \mathrm{a}$ & 0.69 & & SAV & 3.57 & 0.78 \\
\hline & & & & & & UN & 2.70 & 1.12 \\
\hline & & All & 3.18 & 0.85 & & & & \\
\hline \multirow{6}{*}{$3 b$} & \multirow{6}{*}{$\begin{array}{l}F=5.66 \\
p<0.01\end{array}$} & $18-24$ & $2.97 \mathrm{c}$ & 1.15 & \multirow{5}{*}{$\begin{array}{l}\mathrm{F}=3.40 \\
p<0.05\end{array}$} & GOV & $3.70 \mathrm{a}$ & 0.77 \\
\hline & & $25-35$ & $3.56 \mathrm{~b}$ & 0.78 & & PS & $3.51 \mathrm{a}$ & 0.84 \\
\hline & & $36-50$ & $3.63 b$ & 0.83 & & NGO & $3.66 \mathrm{a}$ & 0.81 \\
\hline & & $>50$ & $3.94 \mathrm{a}$ & 0.41 & & SAV & $3.28 \mathrm{a}$ & 0.75 \\
\hline & & & & & & UN & $2.75 b$ & 1.33 \\
\hline & & All & 3.40 & 0.98 & & & & \\
\hline \multirow{6}{*}{$3 c$} & \multirow{6}{*}{$\mathrm{F}=0.15, \mathrm{n} . \mathrm{s}$} & $18-24$ & 3.36 & 0.99 & \multirow{5}{*}{$\mathrm{F}=1.44, \mathrm{n} . \mathrm{s}$} & GOV & 3.51 & 0.89 \\
\hline & & $25-35$ & 3.43 & 0.84 & & PS & 3.56 & 0.83 \\
\hline & & $36-50$ & $\begin{array}{l}3.52 \\
3.44\end{array}$ & $\begin{array}{l}0.69 \\
0.85\end{array}$ & & NGO & 3.66 & 0.81 \\
\hline & & $>50$ & & & & SAV & 3.57 & 0.53 \\
\hline & & & & & & UN & 3.05 & 0.99 \\
\hline & & All & 3.42 & 0.87 & & & & \\
\hline \multirow{6}{*}{$3 d$} & \multirow{6}{*}{$\begin{array}{l}\mathrm{F}=4.39 \\
p<0.01\end{array}$} & $18-24$ & $4 a$ & 0.74 & \multirow{5}{*}{$\mathrm{F}=1.38, \mathrm{n} . \mathrm{s}$} & GOV & 3.77 & 0.84 \\
\hline & & $25-35$ & $3.56 \mathrm{~b}$ & 0.78 & & PS & 3.60 & 0.80 \\
\hline & & $36-50$ & $3.89 \mathrm{ab}$ & 0.65 & & NGO & 4.33 & 0.51 \\
\hline & & $>50$ & $3.27 \mathrm{bc}$ & 0.89 & & SAV & 3.57 & 0.53 \\
\hline & & & & & & UN & 3.90 & 0.85 \\
\hline & & All & 3.75 & 0.80 & & & & \\
\hline \multirow{6}{*}{$3 e$} & \multirow{6}{*}{$\mathrm{F}=0.92, \mathrm{n} . \mathrm{s}$} & $18-24$ & 3.73 & 0.94 & \multirow{5}{*}{$\mathrm{F}=1.39, \mathrm{n} . \mathrm{s}$} & GOV & 3.85 & 0.81 \\
\hline & & $25-35$ & 3.43 & 0.78 & & PS & 3.46 & 0.71 \\
\hline & & $36-50$ & 3.57 & 0.76 & & NGO & 3.83 & 0.75 \\
\hline & & $>50$ & 3.38 & 0.69 & & SAV & 3.28 & 0.48 \\
\hline & & & & & & UN & 3.45 & 1.14 \\
\hline & & All & 3.75 & 0.80 & & & & \\
\hline
\end{tabular}




\begin{tabular}{|c|c|c|c|c|c|c|c|c|}
\hline \multirow{6}{*}{$3 \mathrm{f}$} & \multirow{5}{*}{$\mathrm{F}=1.72, \mathrm{n} . \mathrm{s}$} & $18-24$ & 3.61 & 0.94 & \multirow{5}{*}{$\mathrm{F}=1.44, \mathrm{n} . \mathrm{s}$} & GOV & 4 & 0.83 \\
\hline & & $25-35$ & 3.65 & 0.88 & & PS & 3.78 & 0.82 \\
\hline & & $36-50$ & $\begin{array}{c}4.05 \\
4\end{array}$ & $\begin{array}{l}0.77 \\
0.68\end{array}$ & & NGO & 3.50 & 0.83 \\
\hline & & $>50$ & & & & SAV & 4 & 0.57 \\
\hline & & & & & & UN & 3.45 & 1.05 \\
\hline & & All & 3.77 & 0.87 & & & & \\
\hline \multirow{6}{*}{$3 g$} & \multirow{6}{*}{$\begin{array}{l}\mathrm{F}=3.13, \\
p<0.05\end{array}$} & $18-24$ & $3.21 \mathrm{~b}$ & 0.94 & \multirow{5}{*}{$\mathrm{F}=0.48, \mathrm{n} . \mathrm{s}$} & GOV & 3.59 & 0.93 \\
\hline & & $25-35$ & $3.34 \mathrm{~b}$ & 0.95 & & PS & 3.46 & 0.97 \\
\hline & & $36-50$ & $4 a$ & 0.81 & & $\mathrm{NGO}$ & 3.66 & 1.03 \\
\hline & & $>50$ & $3.72 \mathrm{a}$ & 0.89 & & SAV & 3.85 & 0.69 \\
\hline & & & & & & UN & 3.20 & 0.95 \\
\hline & & All & 3.48 & 0.94 & & & & \\
\hline \multirow{6}{*}{$\begin{array}{c}\text { SE- } \\
\text { Index }\end{array}$} & \multirow{6}{*}{$\mathrm{F}=1.64, \mathrm{n} . \mathrm{s}$} & $18-24$ & 23.82 & 4.04 & \multirow{5}{*}{$\begin{array}{l}F=2.81, \\
p<0.05\end{array}$} & GOV & $25.88 \mathrm{a}$ & 3.32 \\
\hline & & $25-35$ & 24.47 & 3.70 & & PS & $24.68 \mathrm{a}$ & 3.27 \\
\hline & & $36-50$ & 25.89 & 2.57 & & $\mathrm{NGO}$ & $24.66 \mathrm{a}$ & 1.96 \\
\hline & & $>50$ & 25.16 & 2.99 & & SAV & $25.14 \mathrm{a}$ & 1.06 \\
\hline & & & & & & UN & $22.50 \mathrm{~b}$ & 4.66 \\
\hline & & All & 24.60 & 3.59 & & & & \\
\hline
\end{tabular}

Nevertheless, future projections about precipitation showed seasonal differences. It is expected that spring precipitation increases faster in relation to other seasons, especially in the end of the 21 st century ${ }^{30}$.

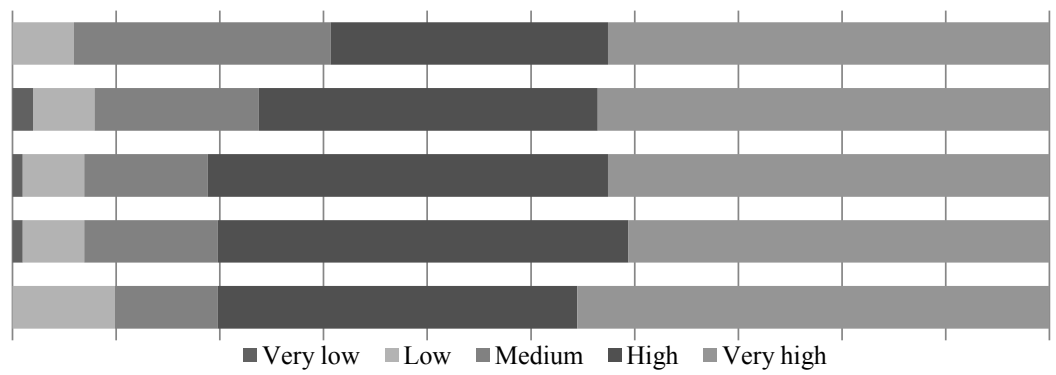

Figure 5. Relative percentage of the answers to the proposed local stakeholders measures regarding the impacts of the urban sprawl in Vilnius

30 Bukantis, A.; Rimkus, E. 2005. Climate Variability and Change in Lithuania. Acta Zoologica Lituanica. 15(2): 100-104. 
The respondents had less concern about the effects of the urban sprawl in geohazards. Previous studies showed that urban sprawl can significantly increase the risk of landslides ${ }^{31}$. According to $\mathrm{WHO}^{32}$, the majority of Lithuanian territory has a very low to low risk of natural triggered landslides. They occur especially near rivers during spring floods. Artificial landslides are related with urban expansion of the largest cities, such as Vilnius or Kaunas. In Vilnius, landslides are considered the biggest geo-hazards and cause important economic losses ${ }^{33}$. The urban expansion is the major trigger of landslides in Vilnius, especially in the construction near slopes and inappropriate planning of sloped $\operatorname{areas}^{34}$. However, despite the risk, they are not frequent and this may have influenced the respondents understanding.

The urban sprawl is a threat to protected areas and biodiversity ${ }^{35}$ and, as previous studies shown, in the major cities in Lithuania expansion is not sustainable and does not respect the master plan, affecting directly or indirectly natural areas located nearby ${ }^{36}$. The construction of new urbanizations exacerbate the demand of building materials $^{37}$, energy and water consumption ${ }^{38}$. In the period of 2001-2012, there was an increase of water consumption from $24.904 \mathrm{~m}^{3}$ to $28.133 \mathrm{~m}^{3}$ (13\%) in Vilnius. In the same period, an increase of the domestic and industrial wastewater discharge from

31 Cabral, P.; Santos, J.A.; Augusto, G. 2011. Monitoring Urban Sprawl and the National Ecological Reserve in Sintra-Cascais. Journal of Urban Planning and Development. 137(3): 346-353.; Rojas, C.; Pino, J.; Basnou, C.; Vivanco, M. 2013. Assessing Land-Use and Cover Changes in Relation to Geographic Factors and Urban Planning in the Metropolitan Area of Concepcion (Chile). Implications for Biodiversity Conservation. Applied Geography. 39: 93-103.

32 WHO (2010)http://data.euro.who.int/e-atlas/europe/images/map/lithuania/ltu-landslides.pdf

33 Cyžienè, J.; Minkevičius, V.; Mikulènas, J.; Satkunas, L.G.T. 2012. Geohazard Description for Vilnius. PanGe Report [interactive]. [accessed on 2013-11-14]. <http://www.pangeoproject.eu/ pdfs/vilnius/Geohazard-Description-vilnius.pdf $>$.

34 Morkūnaite, R.; Česnulevičius, A. 2005. Recent Investigations of the Peculiarities of Vilnius Relief Dynamics. Proceedings of Estonian Academy of Sciences Geology. 54(3): 191-203.

35 Paul, V.; Tonts, M. 2005. Containing Urban Sprawl: Trends in Land Use and Spatial Planning in the Metropolitan Region of Barcelona. Journal of Environmental Planning and Management. 48(1): 7-35.; Selva, N.; Kreft, S.; Kati, V.; Schulck, M.; Jonsson, B.G.; Mihok, B.; Okarama, H.; Ibisch, P.L. 2011. Roadless and Low-Traffic Areas as Conservation Targets in Europe. Environmental Management. 48(5): 865-877.

36 Lazdinis, I. 2009. Legal Aspects of Managing Recreational Forest in the Republic of Lithuania: Case Study of Vilnius Town Forest Management. Environmental Research, Engineering and Management. 4(50): 76-82.; Dringelis, L.; Romanauskas, E.; Gudzinevičiūtè, G. 2011. The Use of Land in Master Plans of Towns from the Point of View of Sustainable Spatial Development. Environmental Research, Engineering and Management. 4(58): 65-73.; Burneika, D.; Ubarevičienè, R. 2011. The Sprawl of Vilnius City - Some Consequences of Rural-Urban Transformations. Annales Geographicae. 43-44: 108-115.

37 Winston, N. 2010. Regeneration for Sustainable Communities? Barriers to Implementing Sustainable Houses in Urban Areas. Sustainable Development. 18(6):319-330.

38 Johnson, M.P. 2001. Environmental Impacts of Urban Sprawl: A Survey of the Literature and Proposed Research Agenda. Environmental and Planning A. 33(4): 717-735. 
$39.908 \mathrm{~m}^{3}$ to $42.597 \mathrm{~m}^{3}(7 \%)^{39}$ was observed, which may be also attributed to urban expansion. It is well known that wastewater discharge reduces the water quality and quantity. The substitution of a forest cover reduces the infiltration and increases the runoff. Due to urban activities, the deposition of pollutants is high. This makes it easy to transport by runoff after storms and transport to underground and surface water bodies $^{40}$. Urban sprawl increases the traffic and air pollution and, as a consequence, the $\mathrm{CO}_{2}$ levels in the atmosphere ${ }^{41}$. The increase of the number of private cars and the daily traffic jams in urban and suburban areas are the main causes of pollution and $\mathrm{CO}_{2}$ increase ${ }^{42}$. Between 2004 and 2012, there was an increase of 9 to 12 thousand passenger cars in Lithuania ${ }^{43}$. In Vilnius, traffic jams are a recognized problem attributed to daily travels from the suburbs to the city center ${ }^{44}$, with important implications in street noise ${ }^{45}$. Overall, the respondents seem to be more concerned with aspects related to landscape aesthetics (e.g., impact in protected areas), economy (e.g., energy and water consumption) and impacts on human health (air and noise pollution) rather than land consumption aspects.

Table 4. a) Urban sprawl local stakeholders responses and stakeholders index (STK_Index), b) according to the age and profession of the participants. Significant differences were considered at $p<0.05$. Government (GOV), private sector (PS), nongovernmental organization (NGO), municipality (SAV) and the unemployed (UN).

39 Lithuanian Statistics Portal [interactive]. [accessed on 2013-11-03]. <http://www.osp.stat.gov.lt>.

40 Frumkin, H. 2002. Urban Sprawl and Public Health. Public Health Reports. 117(3): 201-217.;

Harrison, M.; Stanwyck, E.; Beckingham, B.; Starry, O.; Hanlon, B.; Newcomer, J. 2012. Smart Growth and the Septic Tank: Wastewater Treatment and Growth Management in the Baltimore Region. Land Use Policy. 29(3): 483-492

41 Nechyba, T.J.; Walsh, R. 2004. Urban Sprawl. Journal of Economical Perspectives. 18(4): 177200.; Bereitschaft, B.; Debbage, K. 2013. Urban Form, Air Pollution and CO2 Emissions in Large U.S. Metropolitan Areas. The Professional Geographer. 65(4): 612-635.

42 Wang, H.; Fu, L.; Zhou, Y.; Ge, W. 2010. Trends in Vehicular Emissions in China's Mega Cities from 1995-2005. Environmental Pollution. 158(2): 394-400.; EEA. 2013. Air Quality in Europe - 2013 Report. European Environmental Agency Report. 9: 107.

43 EEA. 2012b. Monitoring CO2 Emissions from New Passenger Cars in the EU: Summary of Data of 2012. European Environmental Agency Report, p. 24.

44 Vitkūnas, R.; Meidute, I. 2011. Evaluation of Bypass Influence on Reducing Air Pollution in Vilnius City. Transport. 26(1): 43-49.; Pumputis, V.; Garbinčius, G.; Mironov, V. 2013. Traffic Management Facilities Used at Intersection of Ukmerges and Gelezinio Vilko Streets. Transport and Telecommunication Journal. 14(3): 187-195.

45 Jagniatinskis, A.; Fiks, B.; Mickaitis, M. 2011. Statistical Assessment of Environmental Noise Generated by Road Traffic. Transport. 26(1): 96-105. 


\begin{tabular}{|c|c|c|c|c|c|c|c|c|}
\hline $\begin{array}{l}\text { Ques- } \\
\text { tion }\end{array}$ & $F$ & Age & Mean & SD & F & $\begin{array}{c}\text { Pro- } \\
\text { fession }\end{array}$ & Mean & SD \\
\hline \multirow{6}{*}{$4 \mathrm{a}$} & \multirow{6}{*}{$\begin{array}{l}F=3.37 \\
p<0.05\end{array}$} & $18-24$ & $3.78 \mathrm{~b}$ & 1.03 & \multirow{5}{*}{$\mathrm{F}=1.54, \mathrm{n} . \mathrm{s}$} & GOV & 4.14 & 1.02 \\
\hline & & $25-35$ & $3.95 \mathrm{ab}$ & 0.82 & & PS & 3.95 & 0.83 \\
\hline & & $36-50$ & $4.47 \mathrm{a}$ & 0.90 & & NGO & 3.50 & .37 \\
\hline & & $>50$ & $4.38 \mathrm{a}$ & 0.77 & & SAV & 4.71 & 0.75 \\
\hline & & & & & & UN & 4.10 & 0.96 \\
\hline & & All & 4.05 & 0.95 & & & & \\
\hline \multirow{6}{*}{$4 b$} & \multirow{6}{*}{$\begin{array}{l}\mathrm{F}=3.09, \\
p<0.05\end{array}$} & $18-24$ & $3.82 \mathrm{~b}$ & 1.02 & \multirow{5}{*}{$\mathrm{F}=1.26, \mathrm{n} . \mathrm{s}$} & GOV & 4.15 & 1.13 \\
\hline & & $25-35$ & $4 \mathrm{~b}$ & 1.04 & & PS & 4.09 & 0.99 \\
\hline & & $36-50$ & $4.31 \mathrm{a}$ & 1.05 & & NGO & 3.50 & 0.54 \\
\hline & & $>50$ & $4.61 \mathrm{a}$ & 0.67 & & SAV & 4.71 & 0.48 \\
\hline & & & & & & UN & 4 & 1.02 \\
\hline & & All & 4.09 & 1.00 & & & & \\
\hline \multirow{6}{*}{$4 c$} & \multirow{6}{*}{$\mathrm{F}=0.65, \mathrm{n} . \mathrm{s}$} & $18-24$ & 4.17 & 1.05 & \multirow{5}{*}{$\mathrm{F}=0.18, \mathrm{n} . \mathrm{s}$} & GOV & 4.11 & 0.89 \\
\hline & & 25-35 & 4.13 & 0.91 & & PS & 4.15 & 0.98 \\
\hline & & $\begin{array}{c}36-50 \\
>50\end{array}$ & $\begin{array}{l}4.36 \\
3.94\end{array}$ & $\begin{array}{l}0.76 \\
0.80\end{array}$ & & NGO & 4.33 & 1.21 \\
\hline & & & & & & SAV & 4.14 & 0.69 \\
\hline & & & & & & UN & 4.20 & 0.89 \\
\hline & & All & 4.15 & 0.92 & & & & \\
\hline \multirow{6}{*}{$4 \mathrm{~d}$} & \multirow{6}{*}{$\mathrm{F}=0.73, \mathrm{n} . \mathrm{s}$} & $18-24$ & 4.12 & 0.92 & \multirow{5}{*}{$\mathrm{F}=0.87, \mathrm{n} . \mathrm{s}$} & GOV & 4.16 & 1.13 \\
\hline & & $25-35$ & 3.91 & 1.12 & & PS & 4.07 & 0.84 \\
\hline & & $36-50$ & 4.31 & 0.88 & & NGO & 3.66 & 1.21 \\
\hline & & $>50$ & 4.22 & 0.64 & & SAV & 4 & 0.57 \\
\hline & & & & & & UN & 4.4 & 0.75 \\
\hline & & All & 4.12 & 0.92 & & & & \\
\hline \multirow{6}{*}{$4 \mathrm{e}$} & \multirow{6}{*}{$\mathrm{F}=1.05, \mathrm{n} . \mathrm{s}$} & $18-24$ & 4 & 1.04 & \multirow{5}{*}{$\mathrm{F}=0.41, \mathrm{n} . \mathrm{s}$} & GOV & 4.29 & 1.03 \\
\hline & & $25-35$ & 4.08 & 0.99 & & PS & 4.07 & 0.95 \\
\hline & & $36-50$ & 4.36 & 0.89 & & NGO & 3.83 & 1.16 \\
\hline & & $>50$ & 4.38 & 0.77 & & SAV & 4.28 & 0.75 \\
\hline & & & & & & UN & 4.20 & 0.95 \\
\hline & & All & 4.15 & 0.96 & & & & \\
\hline \multirow{6}{*}{$\begin{array}{l}\text { STK- } \\
\text { Index }\end{array}$} & \multirow{6}{*}{$\mathrm{F}=1.88, \mathrm{n} . \mathrm{s}$} & $18-24$ & 19.90 & 3.88 & \multirow{5}{*}{$\mathrm{F}=0.68, \mathrm{n} . \mathrm{s}$} & GOV & 20.85 & 3.93 \\
\hline & & $25-35$ & 20.08 & 3.96 & & PS & 20.34 & 3.67 \\
\hline & & $36-50$ & 21.84 & 3.38 & & NGO & 18.83 & 3.65 \\
\hline & & $>50$ & 21.55 & 2.06 & & SAV & 21.85 & 1.95 \\
\hline & & & & & & UN & 20.90 & 3.49 \\
\hline & & All & 20.60 & 3.60 & & & & \\
\hline
\end{tabular}


Previous studies showed that urban sprawl has important implications on human health. For example, in sprawled cities, people have tendency to be more obese. This is attributed to the lifestyles of residents in sprawled cities, including spending more time in front of TV, less exercising, walking and riding bicycle, driving car for short distance dislocations and the time spent in the $\operatorname{cars}^{46}$. Urban expansion increases the risk of motor vehicles crash, pedestrian injuries, stress and nervous disruption, and diseases related with air pollution, such as respiratory and cardiovascular problems, pregnancies risk, allergies and asthma ${ }^{47}$. The younger and government employers were more concerned with the increase of air pollution. Also, the latter group was more worried with aspects related with impacts on protected areas and traffic problems. This suggests that there is a generational change regarding the problem of air pollution. The work position seems to raise awareness in some important environmental impacts

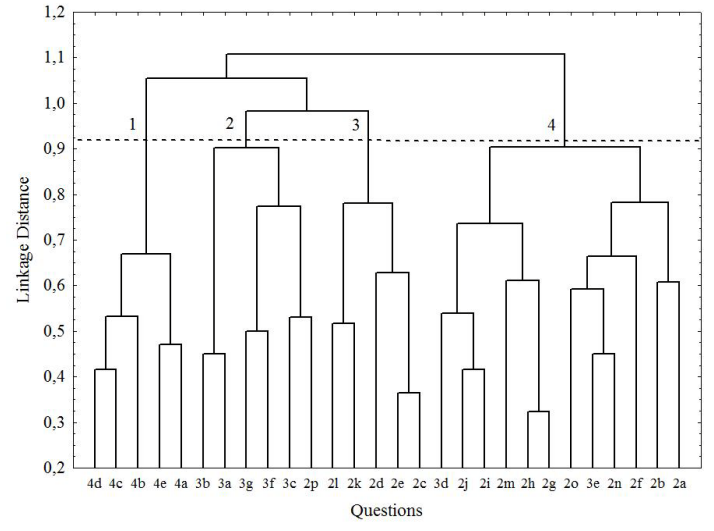

Figure 6. Dendrogram of the relationship between the questions. The dotted line represents the "cut line" and the numbers indicate the groups identified of urban sprawl. The higher ratings obtained in air pollution and traffic congestions shown that the respondents were concerned about the daily impacts of urban sprawl rather than long-term impacts which are not perceptible, long-term and irreversible impacts, such as soil consumption and nature resources depletion. Smart Growth and the Septic Tank: Wastewater Treatment and Growth Management in the Baltimore Region. Land Use Policy. 29(3): 483-492; Lopez, R. 2004. Urban Sprawl and Risk for Being Overweight or Obese. American Journal of Public Health. 94(9): 1574-1579.; Frank, L.D.; Andresen, M.; Schmid, T.L. 2004. Obesity Relationship with Community Design, Physical Activity, and Time Spent in Cars. American Journal of Preventive Medicine. 27(2): 87-96.; Ewing, R.; Brownson, R.C.; Berrigan, D. 2006. Relationship between Urban Sprawl and Weight of United States Youth. Amercan Journal of Prevention Medicine. 31(6): 464-474.

47 Frumkin, H. 2002. Urban Sprawl and Public Health. Public Health Reports. 117(3): 201-217. Harrison, M.; Stanwyck, E.; Beckingham, B.; Starry, O.; Hanlon, B.; Newcomer, J. 2012. Smart Growth and the Septic Tank: Wastewater Treatment and Growth Management in the Baltimore Region. Land Use Policy. 29(3): 483-492; Ewing, R.; Schmidt, T.; Killingsworth, R.; Zlot, A.; Raudenbush, S. 2003. Relationship Between Urban Sprawl and Physical Activity, Obesity, and Morbidity. American Journal of Health Promotion. 18(1): 47-57.; EEA, 2013b) 


\section{Urban sprawl socio-economic impacts}

The respondents had a great concern about the aspects related to urban sprawl effects, including all the economical questions, such as household expenditure, travelling long distances, the cost of the congestion, the inefficient transport systems, the expenses in water and sewage facilities and the lack of use of abandoned industrial areas. Low density urbanization reduces the contact among people creating "ghettos" based on social, cultural and economic status ${ }^{48}$. In Vilnius, the urban sprawl is creating tensions between Polish and Lithuanian communities. Lithuanians are suburbanizing the surrounding areas of Vilnius where Polish ethnic groups are in majority, with different culture, social and economic styles of life. This process may increase the problems among both communities ${ }^{49}$. The necessity of daily long distances increases the household expenditure, especially because many of the inhabitants use a private car in their daily travels ${ }^{50}$. The intensive use of private cars leads to intense traffic congestions and increases the household costs, due to travel duration ${ }^{51}$. In addition, it contributes to the inefficiency of public transport, making ineffective any measure carried out to reduce traffic circulation.

Urban expansion increases the demands of water and sewage infrastructures that normally are supported by the municipalities. In the first period, these new urbanizations grow without any previous basic services, and waste water is discharged in septic tanks, with coercive implications to soil, groundwater and surface water pollution $^{52}$. Later, after water and sewage systems construction, these expenses are charged in the inhabitants of the new areas. This significantly increases the costs of living in these areas and the costs of public services ${ }^{53}$. In Vilnius region, in rural and

48 Le Goix, R. 2005. Gated Communities: Sprawl and Social Segregation in Southern California. Housing Studies. 20(2): 323-343.; Brueckner, J.K.; Largey, A.G. 2008. Social Interaction and Urban Sprawl. Journal of Urban Economics. 64(1): 18-34.

49 Ubarevičiene, R. et al, supra note 13.

50 Buliung, R.N.; Kanaroglou, P.S. 2006. Urban Form and Household Activity-Travel Behaviour. Growth and Change. 37(2): 172-199.

51 Brueckner, J.K. 2013. Elements of an Ideal Urban Policy. The Korean Economic Review. 29(1): 5-22.

52 Klug, S.; Hayashi, Y. 2012. Urban Sprawl and Local Infrastructure in Japan and Germany. Journal of Infrastructure Sytems. 18(4): 232-241.; Harrison, M.; Stanwyck, E.; Beckingham, B.; Starry, O.; Hanlon, B.; Newcomer, J. 2012. Smart Growth and the Septic Tank: Wastewater Treatment and Growth Management in the Baltimore Region. Land Use Policy. 29(3): 483492; Hill, T.; Huhner, T.; Kreibich, V.; Lindner, C. 2014. Dar es Salam, Megacity of Tomorrow: Informal Urban Expansion and the Provision of Technical Infrastructure. In: Kraas et al. (eds.). Megacities: Our Global Urban Future. International Year of Planet Earth, p. 165-177.

53 Hortas-Rico, M.; Sole-Olle, A. 2010. Does Urban Sprawl Increase the Costs of Providing Local Public Services? Evidence from Spanish Municipalities. Urban Studies. 47(7): 1513-1540.; Lieske, S.N.; McLeod, D.M.; Coupal, R.H.; Sanjeev, K.S. 2012. Determining the Relationship between Urban Form and the Costs of Public Services. Environment and Planning B: Planning and Design. 39(1): 155-173. 
urban areas in 2001 the number of dwellings with sewerage was 185.780 and in 2011 it reached $228.084^{54}$.This represents an increase of $22.77 \%$ that can be attributed not only to the better provision of sanitation measures, but also to the sprawl of new urbanizations.

Brownfield are abandoned terrains or sub-utilized sites that are suspected to be polluted. They are located in the centre of urban areas and are well connected. The use of these areas is the key aspect to reduce the urban sprawl and their impact in the environment, social and economic dimensions $s^{55}$. Despite the potential contamination of these areas, it is important to create some initiatives to recover it and reuse it as residential, commercial or green areas ${ }^{56}$. Brownfields re-use is a land use strategy that favours the long-term sustainable development as opposed to the urban expansion, fast economic growth and resource depletion. These measures promote job creation and issues related to health and safety ${ }^{57}$. In Lithuania, the total contaminated area is higher than 5 million $\mathrm{m}^{2}$ that is attributed to former Soviet installations. In Vilnius city, there are several brownfield areas ${ }^{58}$ that could be reused in new residential areas and reduce the present urban sprawl.

The respondents were less concerned with the impact of sprawl in social and economic segregation. The expansion of new urbanizations is a cause of social isolation and reduction of interaction ${ }^{59}$. The reason that the interviewed gave less importance to this question may be related to the existence of new technologies that facilitate the communication among people and neighbours. The older respondents were more concerned with the social and economic division, segregation of residential areas and costs with water and sewage. Government, NGO, private sector and municipality workers were also more worried with the urban sprawl impacts in segregation of residential areas. These results suggested that older respondents value more the personal contact among people and may not be users of new technologies, while younger respondents were not so concerned, because nowadays the contact is facilitated with internet usage. The younger respondents were more worried with the household expenditure and travelling long distances than the older respondents

54 Lithuanian Statistics Portal [interactive]. [accessed on 2013-11-03]. <http://www.osp.stat.gov.lt>.

55 McCarthy, L. 2002. The Brownfield Dual Land Use Policy Challenge: Reducing Barriers to Private Redevelopment while Connecting Reuse to Broader Community Goals. Land Use Policy. 19(4): 287-296.

56 Buzbee, W.W. 1999. Urban Sprawl, Federalism, and the Problem of Institutional Complexity. Fordham Law Review. 68(1): 57-136.

57 Dorsey, J.W. 2003. Brownfields and Greenfields: The Intersection of Sustainable Development and Environmental Stewardship. Environmental Practice. 5(1): 69-76.

58 Velykiene, D. 2009. Systematic Approach to Brownfields in Lithuania. Proceedings of the 7th International Scientific and Practical Conference. Volume 1, p. 228-234.

59 Le Goix, R. 2005. Gated Communities: Sprawl and Social Segregation in Southern California. Housing Studies. 20(2): 323-343.; Brueckner, J.K. 2013. Elements of an Ideal Urban Policy. The Korean Economic Review. 29(1): 5-22. 
were. This can be attributed to the higher expenses that this group has and the long time spent in traffic jams. The unemployed group were not so concerned with socioenvironmental aspects in relation to the other groups, perhaps due their current status and the fact that they have different priorities. Overall, the respondents were more worried about the lack of use of brownfields than about the effects of urban expansion, such as social and economic division. This shows that they want to live in more centric areas of the city and move to areas far away from the city, very likely due the price of the apartments.

\section{Local stakeholders responses to urban sprawl}

The interviewed rated high the necessity of creating new policies to reduce impacts of urban sprawl and a more sustainable development. People seek for more regulations to limit urban sprawl. Nevertheless, the solution might not be in the "creation", but in the "respect" and "practice" of the current laws and a more efficient transposition of European Union directives. The implementation of European Union directives also varies in different $\operatorname{countries}^{60}$, and very often there are troubles in European Union directive transposition ${ }^{61}$ that normally are delayed due to the lack of resources, competence, administrative ineffectiveness, lack of experience, political and administrative priority ${ }^{62}$. Sub-national interests may also delay the transposition and implementation of directives ${ }^{63}$. Often, the transposition and implementation of environment, health and social directives are particularly delayed in relation to the others ${ }^{64}$. In the case of environmental issues, transposition is faster when it is important for the government or when green parties are in the government ${ }^{65}$. The older respondents were more concerned with the development of sustainable policies

60 Liefferink, D.; Wiering, M.; Uitenboogaart, Y. 2011. The EU Water Framework Directive. A Multi-Dimensional Analysis of Implementation and Domestic Impact. Land Use Policy. 28(4): $712-722$.

61 Konig, T.; Luetgert, B. 2009. Troubles with Transposition? Explaining Trends in Member State Notification and the Delayed Transposition of EU Directives. British Journal of Political Science. 39(1): 163-194.

62 Berglund, S.; Gange, I.; Waarden, F.V. 2006. Mass Production of Law. Routinization and Transposition of European Directives: A Sociological-Intuitionalist Account. Journal of European Public Policy. 13(5): 962-716.

63 Borghetto, E.; Franchino, F. 2010. The Role of Subnational Authorities in the Implementation of EU Directives. Journal of European Public Policy. 17(6): 759-780.

64 Jordan, A. 1999. The Implementation of EU Environmental Policy: A Policy Problem without a Political Solution. Environment and Planning C: Government and Policy. 17(1): 69-90.; Haverland, M.; Steunenberg, B.; Waarden, F. V. 2011. Sectors at Different Speeds: Analysing Transposition Deficits in the European Union. Journal of Common Market Studies. 49(2): 265291.

65 Spendzharova, A.; Versluis, E. 2013. Issue Salience in European Policy Process: What Impact on Transposition. Journal of European Public Policy. 20(10): 1499-1516. 
to reduce urban sprawl and creation of policies to brownfield areas and renovation of public spaces than the younger respondents were. This shows that the older respondents want the creation of new policies that increase the revitalization of urban areas and make a better use of central urban areas. On average, the respondents ranked high the questions related to the local stakeholders actions (all $>4$ ) than the ones connected with the environment and socio-economic aspects. This confirms the idea that the interviewed seek the solution to urban sprawl reduction in more legislation rather than in social action.

\section{Relation among variables}

The index correlation is high between Env-Index and SE-Index, suggesting that the respondents that rated high environmental questions gave also importance to social and economic aspects. The correlation was weak between Env-Index and STKIndex, and SE-Index and STK-Index, showing that despite the general agreement in environmental and socio-economic aspects, they differ in the political measures to reduce the urban sprawl. The first group identified by the cluster analyses joined the local stakeholders measures, which demand for more legislation. The older respondents from the government and municipalities rated these questions high, which shows that they defend a better legislation to control sprawl. The second group joined the older respondents concerned with the urban sprawl impacts on social and land use aspects that were mainly from government and NGO. This group wants the existence of a compact city, where the brownfields have a better use and the reduction of socio-economic impacts of urban sprawl. The third group joined the older respondents from the government and NGO that were concerned with the impacts of urban sprawl in rural and protected areas (resources depletion and pollution). The fourth group joined the young respondents from NGO and government that valued more the impact of urban expansion in consumption aspects, environmental and agriculture losses and impacts on urban environment. Overall, the older respondents were more concerned with the lack of legislation and impacts of the incorrect land use and implications of urban sprawl in socio-economic aspects in rural areas, while the younger respondents were focused on consumerism aspects and impacts in the urban environment. These results suggest that there is a change in the perception of urban sprawl impacts, very likely due to the fact that younger people are more connected with urban environments, whereas the older generation is more related to the rural areas.

\section{Conclusions}

Urban sprawl has important negative environmental, social and economic impacts in Vilnius city. These problems were perceived by the respondents, despite the differences in their age, but especially in their profession. Young people from 
NGO and municipality recognized better the problem, and older people from government and municipality claimed for more regulation.

The respondents valued more the aspects related to consumption, pollution and nature protection rather than land degradation and resource depletion, one of the major impacts of urban expansion in the ecosystems. Also, other important aspects were the impacts on human health. Younger people were more concerned with air pollution, whereas government workers were worried with traffic problems and implications of urban sprawl in protected areas. The economic impacts of urban sprawl were considered very important by the respondents, and less importance was given to social and economic segregation. Nevertheless, this aspect was relevant to the older respondents and all professional occupations with exception of the unemployed. This group had less socio-economic concerns of the urban sprawl impacts than the others. In general, the necessity of more regulation were rated higher than the environmental, social and economic aspects of sprawl, especially by the older interviewed people and the workers in municipality and government.

The respondents that were concerned about the urban expansion in the environmental aspects were also concerned in socio-economic questions. The groups identified with the cluster analysis showed that older respondents were more concerned in creating more legislation to restrict urban sprawl and with impacts on rural areas, while young people were concerned about the impact in urban environments.

\section{References}

Arribas-Bel, D.; Nijkamp, P.; Scholten, H. 2011. Multidimensional Urban Sprawl in Europe: A Self-Organizing Map Approach. Computers, Environment and Urban Systems. 35(4): 263-275.

Bardauskienè, D.; Pakalnis, M. 2011. Current Trends and Management of Urban Development in Lithuania. Proceedings Real Corp 2011, Change for Stability: Lifecycles of Cities and Regions. Tagusband: p. 139-144.

Bardauskienė, D.; Pakalnis, M. 2012. Foresighted Urban Planning. Environmental Research, Engineering and Management. 1(59): 63-72.

Bart, I.L. 2010. Urban Sprawl and Climate Change: A Statistical Exploration of Cause and Effect, with Policy Options for the EU. Land Use Policy. 27(2): 283-292.

Bereitschaft, B.; Debbage, K. 2013. Urban Form, Air Pollution and $\mathrm{CO} 2$ Emissions in Large U.S. Metropolitan Areas. The Professional Geographer. 65(4): 612-635.

Berglund, S.; Gange, I.; Waarden, F.V. 2006. Mass Production of Law. Routinization and Transposition of European Directives: A SociologicalIntuitionalist Account. Journal of European Public Policy. 13(5): 962-716.

Borghetto, E.; Franchino, F. 2010. The Role of Subnational Authorities in the Implementation of EU Directives. Journal of European Public Policy. 17(6): 759-780. 
Brueckner, J.K. 2013. Elements of an Ideal Urban Policy. The Korean Economic Review. 29(1): 5-22.

Brueckner, J.K.; Largey, A.G. 2008. Social Interaction and Urban Sprawl. Journal of Urban Economics. 64(1): 18-34.

Bukantis, A.; Rimkus, E. 2005. Climate Variability and Change in Lithuania. Acta Zoologica Lituanica. 15(2): 100 104.

Buliung, R.N.; Kanaroglou, P.S. 2006. Urban Form and Household ActivityTravel Behaviour. Growth and Change. 37(2): 172-199.

Burneika, D.; Ubarevičienè, R. 2011. The Sprawl of Vilnius City Some Consequences of RuralUrban Transformations. Annales Geographicae. 43-44: 108-115.

Burstein, P. 2003. The Impact of Public Opinion on Public Policy: A Review and an Agenda. Political Research Quarterly. 56(1): 29-40.

Buzbee, W.W. 1999. Urban Sprawl, Federalism, and the Problem of Institutional Complexity. Fordham Law Review. 68(1): 57-136.

Cabral, P.; Santos, J.A.; Augusto, G. 2011. Monitoring Urban Sprawl and the National Ecological Reserve in SintraCascais. Journal of Urban Planning and Development. 137(3): 346-353.

Catalan, B.; Sauri, D.; Serra, P. 2008. Urban Sprawl in the Mediterranean: Patterns of Growth and Change in the Barcelona Metropolitan Region. Landscape and Urban Planning. 85(34): $174-184$.

Cirtautas, M. 2013. Urban Sprawl of Major Cities in the Baltic States. Architecture and Urban Planning. 7: 72-79.

Depietri, Y.; Renaud, F.G.; Kallis, G. 2012. Heat Waves and Floods in Urban Areas: A Policy-Oriented Review of Ecosystems Services. Sustainability Science. 7(1): 95-107.
Dorsey, J.W. 2003. Brownfields and Greenfields: The Intersection of Sustainable Development and Environmental Stewardship. Environmental Practice. 5(1): 69-76.

Dringelis, L.; Romanauskas, E.; Gudzinevičiūtè, G. 2011. The Use of Land in Master Plans of Towns from the Point of View of Sustainable Spatial Development. Environmental Research, Engineering and Management. 4(58): 65-73.

EEA. 2006. Urban Sprawl in Europe. The Ignored Challenge. European Environmental Agency Report. 10: 56.

EEA. 2012a. Urban Adaptation to Climate Change in Europe. Challenges and Opportunities for Cities Together with Supportive National and European Policies. European Environmental Agency Report. 2: 143.

EEA. 2012b. Monitoring CO2 Emissions from New Passenger Cars in the EU: Summary of Data of 2012. European Environmental Agency Report, p. 24.

EEA. 2013. Air Quality in Europe - 2013 Report. European Environmental Agency Report. 9: 107.

Einfalt, T.; Hatzfeld, F.; Wagner, A.; Seltmann, J.; Castro, D.; Frerichs, S. 2009. URBAS: Forecasting and Management of Flash Floods in Urban Areas. Urban Water Journal. 6(5): 369-374.

European Commission. 2008. Attitudes of European Citizens towards the Environment. Special Eurobarometer 295 Report, p. 127.

European Commission. 2011. Cities of Tomorrow. Challenges, Visions, Ways forward. Directorate General for Regional Policy, p. 100.

Ewing, R.; Brownson, R.C.; Berrigan, D. 2006. Relationship between Urban Sprawl and Weight of United States Youth. Amercan Journal of Prevention Medicine. 31(6): 464-474. 
Ewing, R.; Schmidt, T.; Killingsworth, R.; Zlot, A.; Raudenbush, S. 2003. Relationship Between Urban Sprawl and Physical Activity, Obesity, and Morbidity. American Journal of Health Promotion. 18(1): 47-57.

Frank, L.D.; Andresen, M.; Schmid, T.L. 2004. Obesity Relationship with Community Design, Physical Activity, and Time Spent in Cars. American Journal of Preventive Medicine. 27(2): 87-96.

Frumkin, H. 2002. Urban Sprawl and Public Health. Public Health Reports. 117(3): 201-217.

Harrison, M.; Stanwyck, E.; Beckingham, B.; Starry, O.; Hanlon, B.; Newcomer, J. 2012. Smart Growth and the Septic Tank: Wastewater Treatment and Growth Management in the Baltimore Region. Land Use Policy. 29(3): 483492.

Hasse, J.E.; Lathrop, R.G. 1995. Land Resource Impact Indicators of Urban Sprawl. Applied Geography. 23(2-3): 159-175.

Haverland, M.; Steunenberg, B.; Waarden, F. V. 2011. Sectors at Different Speeds: Analysing Transposition Deficits in the European Union. Journal of Common Market Studies. 49(2): 265-291.

Hill, T.; Huhner, T.; Kreibich, V.; Lindner, C. 2014. Dar es Salam, Megacity of Tomorrow: Informal Urban Expansion and the Provision of Technical Infrastructure. In: Kraas et al. (eds.). Megacities: Our Global Urban Future. International Year of Planet Earth, p. 165-177.

Hirt, S.; Stanilov, K. 2009. Twenty Years of Transition: Evolution of Urban Planning in Eastern Europe and the Former Soviet Union, 1989-2009. UN Habitat, Nairobi, Kenya, p. 146.

Hortas-Rico, M.; Sole-Olle, A. 2010. Does Urban Sprawl Increase the Costs of Providing Local Public Services?
Evidence from Spanish Municipalities. Urban Studies. 47(7): 1513-1540.

Jaeger, J.A.G.; Bertiller, R.; Schwick, C.; Kienast, F. 2010. Suitability Criteria for Measures of Urban Sprawl. Ecological Indicators. 10(2): 397-406.

Jagniatinskis, A.; Fiks, B.; Mickaitis, M. 2011. Statistical Assessment of Environmental Noise Generated by Road Traffic. Transport. 26(1): 96-105. Jelinek, R.; Wood, M.; Hervas, J. 2007. Risk Mapping of Flood Hazards in New Member States. Join Research Center. Institute for the Protection and Security of the Citizen, p. 37.

Johnson, M.P. 2001. Environmental Impacts of Urban Sprawl: A Survey of the Literature and Proposed Research Agenda. Environmental and Planning A. 33(4): 717-735.

Jordan, A. 1999. The Implementation of EU Environmental Policy: A Policy Problem without a Political Solution. Environment and Planning C: Government and Policy. 17(1): 69-90.

Kasanko, M.; Barredo, J.I.; Lavalle, C.; McCormick, N.; Demicheli, L.; Sagris, V.; Brezger, A. 2006. Are European Cities Becoming Dispersed? A Comparative Analysis of 15 European Urban Areas. Landscape and Urban Planning. 77(1-2): 111-130.

Klug, S.; Hayashi, Y. 2012. Urban Sprawl and Local Infrastructure in Japan and Germany. Journal of Infrastructure Sytems. 18(4): 232-241.

Konig, T.; Luetgert, B. 2009. Troubles with Transposition? Explaining Trends in Member State Notification and the Delayed Transposition of EU Directives. British Journal of Political Science. 39(1): 163-194.

Kriaučiūnienè, J.; Jakimavičius, D.; Sarauskienè, D.; Kaliatka, T. 2013. Estimation of Uncertainty Sources in the Projections of Lithuanian River Runoff. Stochastic Environmental 
Research and Risk Assessment. 27(4): 769-784.

Lazdinis, I. 2009. Legal Aspects of Managing Recreational Forest in the Republic of Lithuania: Case Study of Vilnius Town Forest Management. Environmental Research, Engineering and Management. 4(50): 76-82.

Le Goix, R. 2005. Gated Communities: Sprawl and Social Segregation in Southern California. Housing Studies. 20(2): 323-343.

Liefferink, D.; Wiering, M.; Uitenboogaart, Y. 2011. The EU Water Framework Directive. A Multi-Dimensional Analysis of Implementation and Domestic Impact. Land Use Policy. 28(4): 712-722.

Lieske, S.N.; McLeod, D.M.; Coupal, R.H.; Sanjeev, K.S. 2012. Determining the Relationship between Urban Form and the Costs of Public Services. Environment and Planning B: Planning and Design. 39(1): 155-173.

Lithuanian Statistics Portal [interactive]. [accessed on 2013-11-03]. <http:// www.osp.stat.gov.lt $>$.

Lopez, R. 2004. Urban Sprawl and Risk for Being Overweight or Obese. American Journal of Public Health. 94(9): 15741579.

Martinkova, M. 2013. A Review of Applied Methods in Europe for Flood Frequency Analysis in a Changing Environment: Floodfreq COST Action ES0901: European Flood Frequency Estimation. Centre for Ecology and Hydrology, University of Bath, p. 170.

Matijošaitienè, I.; Stankevičè, I. 2011. Hendonomic Roadscapes in the Context of Urban Sprawl. Architecture and Urban Planning. 5: 70-76.

McCarthy, L. 2002. The Brownfield Dual Land Use Policy Challenge: Reducing Barriers to Private Redevelopment while Connecting Reuse to Broader
Community Goals. Land Use Policy. 19(4): 287-296.

Meilutytè-Barauskienè, D.;

Kovalenkovienè, M. 2007. Change of Spring Flood Parameters in Lithuanian Rivers. Energetika. 53(2): 26-33.

Morkūnaitè, R.; Česnulevičius, A. 2005. Recent Investigations of the Peculiarities of Vilnius Relief Dynamics. Proceedings of Estonian Academy of Sciences Geology. 54(3): 191-203.

Nechyba, T.J.; Walsh, R. 2004. Urban Sprawl. Journal of Economical Perspectives. 18(4): 177-200.

Nuissi, H.; Rink, D. 2005. The 'Production' of Urban Sprawl in Eastern Germany as a Phenomena of Post-Socialist Transformation. Cities. 22(2): 123-134.

Paul, V.; Tonts, M. 2005. Containing Urban Sprawl: Trends in Land Use and Spatial Planning in the Metropolitan Region of Barcelona. Journal of Environmental Planning and Management. 48(1): 7-35.

Pumputis, V.; Garbinčius, G.; Mironov, V. 2013. Traffic Management Facilities Used at Intersection of Ukmerges and Gelezinio Vilko Streets. Transport and Telecommunication Journal. 14(3): 187-195.

Rojas, C.; Pino, J.; Basnou, C.; Vivanco, M. 2013. Assessing Land-Use and Cover Changes in Relation to Geographic Factors and Urban Planning in the Metropolitan Area of Concepcion (Chile). Implications for Biodiversity Conservation. Applied Geography. 39: 93-103.

Scalenghe, R.; Marsan, F.A. 2009. The Anthropogenic Sealing of Soils in Urban Areas. Landscape and Urban Planning. 90(1-2): 1-10.

Schwarz, N. 2010. Urban Form Revisited Selecting Indicators for Characterising European Cities. Landscape and Urban Planning. 96(1): 29-47. 
Selva, N.; Kreft, S.; Kati, V.; Schulck, M.; Jonsson, B.G.; Mihok, B.; Okarama, H.; Ibisch, P.L. 2011. Roadless and Low-Traffic Areas as Conservation Targets in Europe. Environmental Management. 48(5): 865-877.

Spendzharova, A.; Versluis, E. 2013. Issue Salience in European Policy Process: What Impact on Transposition. Journal of European Public Policy. 20(10): 1499-1516.

Sung, C.Y.; Yi.; YJ, Li. 2013. Imprevious Surface Regulation and Urban Sprawl as Its Unintended Consequence. Land Use Policy. 32: 317-323.

Travisi, C.M.; Camagni, R.; Nijkamp, P. 2010. Impacts of Urban Sprawl and Commuting: A Modelling Study for Italy. Journal of Transport Geography. 18(3): 382-392.

Ubarevičienè, R.; Burneika, D.; van Ham, M. 2012. Socio-Spatial Transformations, Suburbanization, and Voting Behaviour in the Vilnius Urban Region. IZA Discussion Paper, No.7012, p. 18

Velykienè, D. 2009. Systematic Approach to Brownfields in Lithuania. Procee- dings of the 7th International Scientific and Practical Conference. Volume 1, p. 228-234.

Vitkūnas, R.; Meidutè, I. 2011. Evaluation of Bypass Influence on Reducing Air Pollution in Vilnius City. Transport. 26(1): 43-49.

Wang, H.; Fu, L.; Zhou, Y.; Ge, W. 2010. Trends in Vehicular Emissions in China's Mega Cities from 1995-2005. Environmental Pollution. 158(2): 394400.

Winston, N. 2010. Regeneration for Sustainable Communities? Barriers to Implementing Sustainable Houses in Urban Areas. Sustainable Development. 18(6):319-330.

Yang, J.L.; Zhang, G.L. 2011. Water Infiltration in Urban Soils and Its Effects on the Quantity and Quality of Runoff. Journal of Soils and Sediments. 11(5): 751-761.

Zhao, P. 2010. Sustainable Urban Expansion and Transportation in a Growing Megacity: Consequences of Urban Sprawl for Mobility on the Urban Fringe of Beijing. Habitat International. 34(2): 236-243.

\title{
VISUOMENĖS NUOMONĖS APIE MIESTŲ PLE்TROS IૃTAKĄ APLINKOS, SOCIALINIAMS IR EKONOMINIAMS VEIKSNIAMS VILNIAUS MIESTE TYRIMAS
}

\author{
Paulo Pereira, Algirdas Monkevičius \\ Mykolo Romerio universitetas, Lietuva \\ Hanna Siarova \\ Viešosios politikos institutas, Lietuva
}

Santrauka. Žinoma, kad miestu pletra daro dideli neigiama poveikị aplinkai, socialiniams ir ekonominiams veiksniams. Su teritoriju pletra susije energijos ir vandens vartojimo pokyčiai, oro ir vandens tarša, žmoniu sveikatos problemu gausejjimas, dirvožemio naudojimas ir nusidèvejimas. Šio tyrimo tikslas buvo išanalizuoti skirtingo 
amžiaus ir skirtingo tipo darbovietèse dirbančiu respondentu - Vilniaus miesto gyventoju - nuomonę apie miestu plètros įtaka aplinkai bei socialiniam ekonominiam sektoriui. Paaiškejo, kad tyrimo dalyviai susirūpinę dèl poveikio, kurị sukelia miestu plètra. Jaunesni tyrimo dalyviai, dirbantys NVO arba savivaldybejje, didesnę reikšmę teikè problemoms, o vyresni vyriausybiniu ir savivaldos instituciju darbuotojai teige, kad svarbesnis yra reguliavimas. Respondentai miestu plètros neigiama poveiki aplinkai pirmiausia suvokia kaip užterštumo didejjima bei didèjančias su žmoniu sveikata susijusias problemas, mažiau dèmesio skirta dirvožemio nusidèvejimui ir ištekliu eikvojimui. Jaunesni respondentai didesnę reikšmę teike oro taršai, o vyriausybiniu instituciju darbuotojai transporto problemoms. Jaunesni respondentai buvo labiau susirūpinę dèl ilgu atstumy kelioniu ir namu ūkio išlaidų. Vyresni respondentai labiausiai pabrèže urbanizacijos plètros poveikị kaimišku vietoviu aplinkai, jaunesni tyrimo dalyviai - miestu teritoriju aplinkai. Visi klausimai socialiniu ekonominiu aspektu buvo laikomi labai svarbiais.

Reikšminiai žodžiai: miestu plètra, aplinka, socialiniai ekonominiai veiksniai, visuomenés nuomoné.

Paulo Pereira, Mykolo Romerio universiteto Aplinkos valdymo centro profesorius. Mokslinių tyrimų kryptys: darnus vystymasis, žemėnaudos pokyčiai, dirvožemio tyrimai, aplinkosaugos samprata, gaisrų poveikis ekosistemoms.

Paulo Pereira, Environmental Management Centre, Mykolas Romeris University, Professor. Research interests: Sustainable Development, Land use change, Soil Science, Environmental Perception, Fire Impact in the Ecosystems.

Algirdas Monkevicius, Mykolo Romerio universiteto Aplinkos valdymo centras. Mokslinių tyrimų kryptys: miestų plètra, globalus atšilimas, klimato kaita, darnus vystymasis.

Algirdas Monkevicius, Environmental Management Centre, Mykolas RomerisUuniversity, Master Degree. Research Interests: Urban Sprawl, Global Warming, Climate Change, Sustainable Development.

Hanna Siarova, Viešosios politikos instituto vyresnioji mokslinè bendradarbė. Mokslinių tyrimų kryptys: mokyklinis švietimas, nuskriaustų visuomenès sluoksnių švietimas, švietimo ịvairovè, aplinkosauginis švietimas.

Hanna Siarova, Public Policy and Management Institute, Senior Researcher. Research interests: early childhood and school education, education of disadvantaged groups, diversity in education, environmental education. 